University of Louisville

ThinkIR: The University of Louisville's Institutional Repository

Electronic Theses and Dissertations

$11-2012$

\title{
The hidden help : Black domestic workers in the Civil Rights Movement.
}

Trena Easley Armstrong

University of Louisville

Follow this and additional works at: https://ir.library.louisville.edu/etd

Part of the African American Studies Commons, Civil Rights and Discrimination Commons, and the United States History Commons

\section{Recommended Citation}

Armstrong, Trena Easley, "The hidden help : Black domestic workers in the Civil Rights Movement." (2012). Electronic Theses and Dissertations. Paper 46.

https://doi.org/10.18297/etd/46

This Master's Thesis is brought to you for free and open access by ThinkIR: The University of Louisville's Institutional Repository. It has been accepted for inclusion in Electronic Theses and Dissertations by an authorized administrator of ThinkIR: The University of Louisville's Institutional Repository. This title appears here courtesy of the author, who has retained all other copyrights. For more information, please contact thinkir@louisville.edu. 


\title{
THE HIDDEN HELP: BLACK DOMESTIC WORKERS IN THE CIVIL RIGHTS MOVEMENT
}

By

\author{
Trena Easley Armstrong
}

\author{
A Thesis \\ Submitted to the Faculty of the \\ College of Arts and Sciences of the University of Louisville \\ In Partial Fulfillment of the Requirements \\ For the Degree of \\ Master of Arts \\ Department of Pan-African Studies \\ University of Louisville \\ Louisville, Kentucky
}

December, 2012 
THE HIDDEN HELP: BLACK DOMESTIC WORKERS IN THE CIVIL RIGHTS

\section{MOVEMENT}

By

Trena Easley Armstrong

A Thesis Approved on

November 2, 2012

By the following Thesis Committee:

Theresa Rajack-Talley, Thesis Director

Yvonne V. Jones

Cate Fosl 


\section{ACKNOWLEDGMENTS}

First and foremost, I would like to express my thanks to Dr. Theresa RajackTalley for her guidance and unwavering patience. I would also like to thank my thesis committee, Dr. Yvonne Jones and Dr. Cate Fosl, and many thanks to my family and friends for their encouragement. To my family and friends, I would like to thank each of you for your support. I am very fortunate to have "cheerleaders" who have shown their unconditional love and support. Lastly, I would like to dedicate this research to my mother, Alice Reid. Through her challenges, she has remained my greatest inspiration. 


\section{ABSTRACT \\ THE HIDDEN HELP: BLACK DOMESTIC WORKERS \\ IN THE CIVIL RIGHTS MOVEMENT}

Trena E. Armstrong

November 2, 2012

During the 1960 's, nearly ninety percent of black women in the South worked as domestic servants. While much has been written depicting the dehumanizing and exploitative conditions in which they lived, their contributions to human rights garnered from their subtle acts of resistance and specifically, their involvement in the Civil Rights Movement, has either been undocumented or documented quite minimally. Despite their historical roles and socioeconomic disadvantages, their reach for human agency was beneficial to society. This thesis examines their labor as domestic workers and their participation in the Civil Rights Movement using the qualitative research method of interviews and black feminist theoretical perspective. 


\section{TABLE OF CONTENTS}

\section{PAGE}

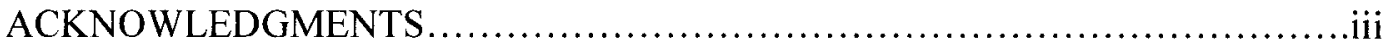

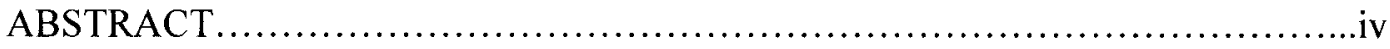

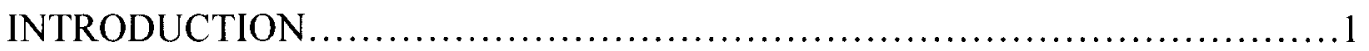

CHAPTER ONE: The History of Domestic Workers.............................7

CHAPTER TWO: Black Domestic Workers in the Civil Rights Movement...........31

CHAPTER THREE: Black Feminism: The Movement \& The Theory $\ldots . . . . . . . . . . .49$

CHAPTER FOUR: Methodological Approach..................................58

CHAPTER FIVE: Findings: Roles and Relationships........................66

CHAPTER SIX: Conclusion......................................... 92

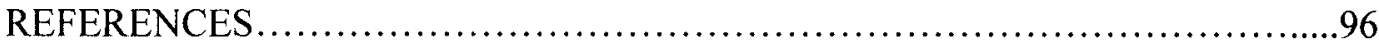

CURRICULUM VITAE................................................... 134 
INTRODUCTION

THE HIDDEN HELP: BLACK DOMESTIC WORKERS IN THE CIVIL RIGHTS

There have been considerable debates concerning The Help since the phenomenal success of both Kathryn Stockett's book and the movie adaptation. One argument questions the abilities of white filmmakers, producers and authors to portray accurate life experiences of African American women. Specifically during the time in which the film is set, many African American women, including the members of the Association of Black Women Historians, felt the atrocities of abuse and racial injustice that African American women experienced were not taken seriously, and depicted as comedic moments (Bracey, 2011; Lee, 2000; Mitchell, 2006). Historically, the life experiences of African American women including that of black domestic workers have been overwhelmingly erroneously depicted in books and film (Bambara, 1970; Dudden, 1983). Their acts of resistance, which catapulted the success of the Civil Rights Movement, have been minimally reported (Evans, 1979).

The purpose of this study is to investigate how black domestic workers negotiated their personal life with their public spheres in the workplace and in the Civil Rights Movement. This includes examining the social relationships between black domestic workers and white employees, the roles they played within the Civil Rights Movement, and how those roles affected their work and personal lives. 
Black women are minimally included in the social history of the U.S. including that of the Civil Rights Movement and other important social changes. Come attention has been given to black women such as Septima Clark, Rosa Parks and others who played vital roles in the Civil Rights Movement. However, research on black domestic workers is limited and tends to focus on either the oppressive environments in which they worked (Collier-Thomas and Franklin, 2001; Olson, 2002) or the stereotype of the happy benevolent Mammy (Anderson, 2000). Both these images reflect strained relationships between the oppressed and the oppressor, and little agency to the black women.

Moreover, black women who worked as domestics during the 1950s and 1960s were generally treated as poor, uneducated, child-like creatures (Thompson, 1988). They were seen as victims of their own ignorance, living in black communities of crime and poverty with high levels of premature pregnancies and other societal infractions. This depiction of black life in white minds was common during the Civil Rights Movement era and was supported by legal racial segregation policies (Bambara, 1970).

For black women who labored as domestic workers in the 1960 s, the racially segregated South became an integral device for altruism, and created innovative meanings for activism. Their trajectories were sometimes difficult due to their gender, and few were ever recognized in the same fashion as Rosa Parks or Fannie Lou Hamer. Governmental enforced discriminatory laws instilled and validated segregation (Collins, 2009; Crawford, Rouse and Woods, 1993).

Segregation proved to be a highly adaptable way of socially organizing a disfranchised group within American society. Racial segregation was a system to keep African Americans in a subordinate status by denying them equal access to public 
facilities and public transportation and equal educational opportunities. Racial segregation in the United States meant segregation of facilities, services, housing, education, employment and transportation based on race. Segregation was a way to legally and socially separate the African Americans in the United States, but it also encompassed other racial and ethnic minorities. As noted by Bullard (2000), legal racial segregation was enforced by law but was finally stopped by the federal government after a series of decisions by the Supreme Court beginning in 1954. Social movements, such as the Civil Rights Movement, prove that, for the most part, in democratic societies different groups have the power to influence their institutions and the culture of their countries in different ways - providing that they are organized to do so and understand the system (legal, political, cultural, and economic) in which they operate (Bloom, 1987).

Although many historians maintain that the Civil Rights Movement began in the 1950s, McGuire (2010) contends the Movement actually began in the 1940s in part as a protest against the ritualistic rape of black women by white men who used sexual violence and terror to derail the freedom movement. As there are variations as to when the Movement began, there are also a number of variations as to how social movements are defined. However, most definitions reflect the notion that they are intrinsically related to bringing about social change. Many of them do encompass the idea that social movements are collective attempts to promote or resist change in a society or group. Further, social movements are conscious collective actions informed of an ideology, aided by an organizational weapon and initiated by a core person or group to bring about change using any means whether violent or non-violent (Benford, Gongaware and Valadez, 2000; Oommen, 1990. In the mid-twentieth century, American sociologists 
characterized social movements as the organized end of a spectrum whose opposite pole was crowds and riots (Blumer 1939; Turner and Killian 1987). They saw social movements as highly organized people interacting to establish new meanings about politics but who sometimes were disorderly and problematic for democracy.

While scholarly discussions of social movements have generally remained distinct, according to Goldberg (1991) they are intimately connected to citizenship and racial identity-formation. He proposed that official policies of exclusion from citizenship according to race have drawn boundaries solidifying subordinated racial identity, which then forms the basis for collective action in response to shifting state policies. This dynamic has generally been overlooked by those theorists of social movements who have focused on relative deprivation, resource mobilization and responses to political opportunities, without explaining the related process of identity formation.

Additionally, Goldberg contends that resistance to the exclusion of citizenship and subordinate racial identity inevitably brings about resistance.

Shorter-Gooden and Jones (2004) argue that African American women have multiple resistance strategies including: (a) ongoing internal coping strategies: (resting on faith-relying on prayer and spirituality; standing on shoulders-drawing strength from African American ancestors; and valuing oneself-sustaining a positive self-image); (b) ongoing external coping strategy - leaning on shoulders, or relying on social support; and (c) specific coping strategies (role flexing-altering their outward behavior or presentation; avoiding—diminishing contact with certain people and situations; and standing up and fighting back-directly challenging the source of the problem. Black domestic workers especially drew heavily upon all aspects of these multiple strategies as 
they worked in private homes of whites while simultaneously working in the Civil Rights Movement (Breines, 2007).

Historically, debates have ensued due to the perceived ambiguity of the public/private place and identity of the domestic worker. Some social scientists felt the nature of domestic work was in conflict with the industrialized capitalist society as no concrete product was being produced. Raaphorst (1988) wrote that domestic work was non-industrial and thus, task-oriented rather than time-oriented, without production of any product. She contributed this to the loss of caste or social status by domestic workers. And while Raaphorst argued that the blurred lines between private and public spheres caused domestic workers the inability to control their work, others such as Cobble (2004) and Fine (2007) state adamantly that African American domestic workers were uniquely positioned to regulate their own labor.

This research adopts a triangulation of qualitative approaches to build on case study of the public and personal lives of black domestic workers. Primary data is collected through interviews with black domestic workers who participated in the Civil Rights Movement in the South and analyzed using a black feminist perspective.

Chapter One encompasses the historical background and development of domestic work. The evolvement of work from an enslaved environment to paid labor, which allowed domestic workers to provide for their families with dignity, is discussed using a timeline of historical developments within American society. It provides a lens in which to view newly freed African-American women with limited skills who obtained monumental achievements within a racially segregated and unjust society.

Chapter Two examines the history of the woman's role within the Civil Rights 
Movement, and that of black domestic workers. It examines how black domestic workers' employment and private lives were impacted due to their participation. The support of their male counterparts and the black church were significant in enabling them to withstand the negative experiences they endured.

Focusing on the intersectionality of race, class, and gender, Chapter Three discusses the multiple roles of black domestic workers as seen through the lens of the black feminist perspective while Chapter Four discusses the methodological approach used for this research and explains the interviewing process of the sample subjects.

Chapter Five reports the findings from the study, and includes the subject's responses to the interview questions. The paper concludes with Chapter Six which discusses how this study compares and deviates from other research, and how it relates to feminist theory. 


\section{CHAPTER ONE: \\ THE HISTORY OF DOMESTIC WORKERS}

A domestic worker is characterized as a person employed by a household to perform various servant duties. The term domestic workers should not be confused with homemakers and housewives, who work in their own home, or housekeepers, who work in institutions such as a hospital or school. The position of employment within a home is a unique and often isolated work environment. The position of a domestic worker is almost always considered "menial" or "inferior" to the family for which they are employed (Palmer, 1989; Sargeant and Giovannone, 2011). Domestic work is undervalued and poorly regulated, and many domestic workers remain overworked, underpaid and unprotected. Accounts of maltreatment and abuse, especially of live-in and migrant domestic workers, are regularly denounced in the media. In some countries, domestic work is very largely performed by child laborers (Coser, 1974; Levenstein, 1962; Wool, 1976).

Paid domestic work remains virtually invisible as a form of employment in many countries, and is part of the informal economy. Domestic work does not take place in a factory or an office, but in the home. The employees are not usually male breadwinners, but overwhelmingly women. They do not work alongside other co-workers, but in isolation behind closed doors. Their work is not aimed at producing added value, but at providing care to millions of households. Domestic work typically entails the otherwise 
unpaid labor traditionally performed in the household by women. This explains why domestic work is undervalued in monetary terms and is often informal and undocumented (Hochschild, 1989; ILO, 2009). It tends to be perceived as something other than regular employment, as not fitting the general framework of existing labor laws despite the fact that its origins go back to the "master-servant" relationship. As a result, the domestic employment relationship is not specifically addressed in many legislative enactments, thus rendering domestic workers vulnerable to unequal, unfair and often abusive treatment (Holzer, 1996; Sharpless, 2010).

Part of the specificity of paid domestic work is that it is often perceived to be something other than employment. Instead, it is commonly claimed that domestic workers are like one of the family (Gilkes, 2000; Hunter, 1998; Kerber, 1998). More often, though, this expression is used to convey the presumed existence of a close, amicable interaction between the employer's family and the domestic worker. It can, however, divert attention from the existence of an employment relationship, in favor of a form of paternalism that is thought to justify domestic workers being asked to work harder and longer for an employer without material reward. In fact, these arrangements are the vestiges of the master--servant relationship, wherein domestic work is a status which attaches to the person performing the work which defines her and limits all future options. Informal norms and some entitlements do develop, but they are subject to a power imbalance that leaves domestic workers without the kind of protection that other workers enjoy in the formal economy (Sen, 1999; Smith, 2011). It is one of the oldest forms of employment for black and minority women, and dates as far back as slavery. 


\section{Slave Women As Domestics}

The goals of slavery were contingent upon the utilization of the productive capacities of everyone including the woman. The black woman was therefore integrated into the productive force. Dictated by the male supremacist ideology of white society in America, the African slave woman was appointed to taking care of the home. Davis' (1995) essay argues that domestic labor was an attempt to complement and confirm her inferiority. According to Davis, while the duties of the African slave woman were to sew, cook, wash, perform housecleaning chores and raise the children of her owner, she was essential to the survival of the black community. Similarly, Tucker (1987) states that the African slave woman's assignment to duties deemed as drudgery helped lay the foundation for some degree of autonomy for her. She experienced instances in which she could move about, on and off the owner's property, away from the watchful eye of her owners. Her circumstances actually pushed her into the center of the slave community.

Overwhelmingly women slave domestics faced different problems from their contemporaries in the fields. Though perhaps better-off materially, domestic slaves often had uncomfortable relations with their white owners. They faced all the potential aggravations of close proximity, from the white women's dissatisfaction and anger, to the sexual threats and rape by owners. More likely, subsequent physical and sexual abuses sustained by black women were not exclusively an attack on her. In some cases, indirectly its target was also an attempt to discourage resistance within the slave community (Jones, 2010; McGuire, 2010; White, 1999). 
There are many studies that document the continuity of resistance, black protest and black insurgent ideologies. Vincent Harding's (1982) study, There Is A River, details the numerous protests that African Americans initiated throughout the slave period and the radical visions associated with these struggles. George Fredrickson's (1996) Black Liberation, also documents how African Americans developed radical ideologies during the nineteenth century that have guided their struggles and played significant roles in liberation ideologies on the continent of Africa. These studies make clear that African Americans have long possessed a protest tradition that is continually refashioned and interjected into new rounds of struggles. Early years in the twentieth century African Americans launched protests directly attacking racial inequality. Between 1900 and 1906 Southern blacks developed boycott movements against Jim Crow streetcars in most major cities of the South (Meier \& Rudwick, 1976;1989). By the turn of the twentieth century Black women had organized local and national clubs through which they relentlessly fought both for the overthrow of Jim Crow and for women's rights (Collier-Thomas, 1984).

The roots of slavery and the devaluation of the work performed by domestic workers are still prevalent in American society. Cohen and Huffman (2003) suggest that gender devaluation is strongest in highly gender-segregated labor markets. One reason for this may be that in segregated markets, men are in a stronger position to benefit from devaluation while women are less able to resist it. The results of their study supported their hypothesis that higher levels of occupational segregation at the labor market level are associated with a significantly increased tendency to devalue women's work roles. 


\section{The Reconstruction (1865-1877)}

In 1868, one of President Andrew Johnson's first acts of Reconstruction was to order all land under federal control to be returned to its previous owners. The Freedmen's Bureau, created to aid millions of former slaves in the postwar era, had to inform the freedmen and women that they could either sign labor contracts with planters or be evicted from the land they had occupied. Those who refused or resisted were eventually forced out by army troops. Most blacks in the rural areas of the South were left without land and forced to work as laborers on large, white-owned farms and plantations in order to earn a living.

In an effort to regulate the labor force and reassert white supremacy in the postwar South, former Confederate state legislatures soon passed restrictive legislation denying blacks legal equality and political rights, and requiring them to sign yearly labor

contracts. During this time it was the predominant capital-labor arrangement throughout the South. With limited skills and an illiterate majority, newly freed blacks contracted as sharecroppers. And while many black women worked alongside men in the fields, a large number of them turned their slave labor skills into paid domestic work. In addition, the low wages paid to black men caused some women to work multiple jobs, alternating between working in the cotton fields during the day, and performing paid cleaning and washing jobs at night. According to the 1890 census, almost forty percent of all black women worked outside the home in domestic and washerwomen occupations (Lemann, 1991; Harrison, 1989; Wilson, 1980). 
During this same time, Barbara Welter (1966) argued that patriarchal ideology had idealized the absolute authority vested in men as heads of communal household enterprises. This, she states, created a cult of true womanhood which arose from the middle classes. She reported that the emerging capitalist economy, however, created industrial and commercial firms which were separate from private households. This caused a new paradigm in which men and women worked together in family enterprises attached to their homes. Middle class men worked in these new firms as owners, professionals, and managers while their wives stayed home.

Deemed as the separation of spheres, Welter (1966) states women and men began to spend long periods of time away from the observation and influence of each other. As women's former status as members of a common enterprise disappeared, a new cultural ideal arose, one that projected a distinctive new identity of women. The ideals of true womanhood gave women special tasks and credited them with special virtues. Women spent her time raising her children and managing a household. At first, this meant taking over all the tasks left in the household after the rise of the market economy. Over time, the middle class household evolved into a sanctuary of private life, in which women created and preserved a haven from the public world. They began employing domestic workers to assist them in upholding the image of domestic perfection. This also elevated and legitimized their homemaker status to that of employer (Ehrenreich and English, 1978; Hartmann, 1974; Margolis, 1984; Rothman, 1978; Strasser, 1982).

While researchers agree that the overwhelming majority of domestics in the United States at that time were European immigrants and African American women (Coser, 1974; Levenstein, 1962; Wool, 1976), there is dispute about the changing- 
character hypothesis (Romero, 1992). For example, Wool (1976) postulated that the historical account reveals that domestic work became low-status, menial and demeaning as a result of the dominating presence of immigrants and non-whites.

On the contrary, Martin and Segrave (1985) argued that in general, domestic work was always viewed as low-status and undesirable but white domestic workers were able to use domestic work as a bridging occupation, while European immigrants and African Americans remained in this occupation due to racism and disenfranchisement. However, black women would eventually obtain access to more desirable and better paying employment as the mobilization of blacks ensued.

\section{The Great Migrations (1879 and 1910)}

The oppressive weight of southern racism became a major push factor, as thousands, and later, millions of African-Americans left the only homes they knew for new opportunities elsewhere. The growing tide of race riots and lynchings were key forces providing enormous impetus to these migrations (Loewen, 2006).

From 1879 to 1898 , the exodus of blacks out of the south began. It was a time when American race relations were thought to have reached their nadir. This was a period in which many blacks established independent, all-black communities in places such as Kansas, Oklahoma, and Nebraska. For blacks, and specifically black women, this move offered better job opportunities as well as better housing (Logan, 1954).

Again, in 1910, more blacks began moving from the south to the north. In addition to their desire to seek employment opportunities in industrial cities (as agricultural mechanization had replaced many of them), and better educational opportunities for their 
children, they wanted to escape racist Jim Crow laws. Jim Crow laws were a legitimization of rigid anti-black racism that denied blacks voting rights, and regulated social interactions between the races in public spaces including transportation and education. Black women migrants often waited years to be reunited with the children and family they left behind (Harrison, 1989; Jones, 1985; Malveaux, 1988; Stetson, 1990).

Excluded from most occupations due to race, black women who migrated North soon dominated the domestic service sector in Chicago. Moreover, they received better wages compared to similar positions in the South, where it took three weeks to earn the same amount as in one week in Chicago in the 1910s.

They were often married with children and hence preferred day work to a livingin situation. By 1920, more domestic workers were living at home than boarding with their employer (Candaele, 1996; Rio, 2005).

In northern cities, black domestic workers found themselves in competition with white immigrants, who organized to keep blacks out of the most menial jobs. Ella Baker and Marvel Cooke (1935) emphasized that no social group was as affected by the Great Depression than black women living in northern cities. In the 1930s in New York City, for instance, black domestic workers desperate for employment gathered on street corners to offer their services to prospective employers. These informal centers of employment became referred to as The Bronx Slave Market. Coble (2006), describes The Bronx Slave Market as an exploitive system whereby white, middle-class women selected daily domestic workers based on worker competition to provide serves at the lowest possible wage. This system, however, only lasted through the Depression and gradually gave way to the growing independence of black domestic workers following World War II. 
The devastation of the Great Depression encouraged attempts to reorganize the occupation of domestic workers. The National Urban League and its various branches partnered with city, state, and national governments to provide both direct and work relief to unemployed domestic workers, including a first-time visiting housekeeper project in New York and Brooklyn that provided caretakers and homemakers to other poor people incapacitated by illness. Along with federal agencies and women's groups, particularly the Women's Bureau and the YWCA, the League sought to upgrade domestic labor through training programs and model contracts (Moore, 1981; Orleck, 1997).

\section{The Great Depression (1929-1941)}

Upon the emergence of the Great Depression, black domestic workers were faced with low wages, and those who were live-ins, were soon faced with being charged extra for room and board and longer working hours. Some black women trained their daughters as domestics in order to help support their families even though this new wave of workers were highly exploited earning one dollar and fifty cents per week for 11 to 12 hours of work per day (Hunter, 1998; Smedley, 2012). Due to the unfair low wages, many domestic workers had gardens which they cultivated and sold produce at open-air markets. This enabled many of them to save so they would not have to work in white's homes during the summer months. They also communicated with each other and would inform domestic worker hopefuls of the whites who paid poorly or were abusive (Berrey, 2009; McGuire, 2010).

This organizing aspect of domestic workers (which would benefit them immensely during the Civil Rights Movement) caused constant irritation and discussions 
among white women employers as they considered it a servant problem (Hurt, 2003; Jones, 2010; Sharpless, 2010). When Tucker interviewed southern white women who were either former domestic employers or children of domestic employers, white women often saw the injustices under which black domestic women lived. But by ascribing strength to black women, white women could ignore these injustices, their part in the continued exploitation and abuse of black domestics, and ignore their own guilt.

Most black domestics had to return to work shortly after childbirth, and regretted that many times they had to leave their children with family or neighbors in order to work. Additionally, Tucker revealed through her interviews that black domestics valued their independence from whites, and felt that having money of their own garnered themselves an independent lifestyle that white women lacked.

\section{The New Deal Era (1933-1936)}

The New Deal ushered in governmental programs such as the visiting housekeeping programs which represented another form of organizing household labor. This was a device used by the government creating new conditions of work in response to social or political pressures. Advocates attempted to deracialize the occupation by emphasizing the presence of white as well as black women, but in fact the programs were designed for black women and reflected how work relief reinforced existing labor market categorizations by race and gender. Former aides stated they considered the job barely a step above domestic work, though much of their job description meant errands for the sick or invalids and housekeeping duties (Cobble, 2004; Fine, 2007; Gray, 1993). 
Explained by Hart (2006), the New Deal policy makers never seriously considered domestic labor. The power of the white South, with its entrenched racism and its dependence on low wages, was a menacing obstacle to coverage of domestics under labor legislation and New Dealers were not about to sacrifice their program for a group of workers whom they had their own doubts could be effectively regulated in the home. It would take a new social movement to place private household workers under the labor law.

The government-funded jobs programs operated first under the Federal Emergency Relief Administration (FERA) and later the Works Progress Administration (WPA) provided government assistance for black domestic workers, but at the price of sustaining traditional relationships of black women's service for white families. According to Palmer's (1989) study, the race/class lines that separated women's housekeeping lives during the era were clearer after examining the Family Disbursement of Wage Earners and Salaried Workers, 1934-1936, a large body of data collected by the Bureau of Labor Statistics in forty-two cities on families with annual incomes between five hundred and three thousand dollars. In contrast to census data that had led most historians to accept the notion that only $5 \%$ of American households hired domestic workers by the 1930s, an analysis of data from six cities in the Family Disbursements survey showed wide regional and intra-racial variations. In Jackson, Mississippi, for instance, only $19 \%$ of white households were unable to hire some domestic work, whether housework or laundry work. The South's peculiar racial power structure loomed much larger than in any other region (Hart, 1994; Smith, 2003). 
On June 25, 1941, the Fair Employment Practices Commission, (FEPC), was established to receive, investigate, and resolve complaints of discrimination by Executive Order 8802. Initiated by President Theodore Roosevelt, the order declared that there would not be any discriminatory practices in the employment of workers in defense industries or government due to race, creed, color, or national origin (Collins, 2001). The FEPC, without direct recourse to penalties, was surprisingly effective in its efforts to promote Roosevelt's anti-discrimnination policy outside of the South, though the Committee appears to have been powerless in the South (Higgs, 1977).

FEPC intervention altered the racial balance some firms struck in their hiring decisions by (1) providing advice on how to integrate the workplace, (2) giving managers a ready excuse for hiring blacks if white workers objected, (3) threatening to bring more powerful government agencies to watch for racist tactics, and/or (4) publicly embarrassing firms and unions that refused to hire blacks. The FEPC opened opportunities to black women in industry.

\section{Domestics in the 19th Century}

Both the demand for household help and the number of black women employed as domestics expanded rapidly in the latter half of the nineteenth century The rise of industrial capital and the elaboration of middle-class standards of cleanliness and largely furnished homes heightened the demand for domestic workers and promoted the idea of women's domestication roles (Chaplin, 1978; Lasch, 1977; Piven and Cloward, 1979).

With the rise of the market economy in the United States, the ideology of women's place in society focused on domesticity. The principal division between the 
roles of women and men had established a link between women's association with children and the home and men's association with paid work and public activity. The market economy made employment (rather than property ownership) the primary determinant of status differences among ordinary people.

Thereafter, men's economic opportunities and freedom from domestic responsibility made them socially superior to women (Hull and Smith, 1997; Kerber, 1998). Women's domesticity reinforced this advantage. The ideals of female domesticity fit this division of labor. As standards of living and family organization changed, the reality and the idealization of women's domesticity changed equally. Because middle class culture reigned over American society, the middle class ideals of women's place were most influential. The idealization of women's domesticity went through transformative stages. The ideal of true womanhood arose in the first half of the nineteenth century. The ideal of a professionalized housewife became prominent at the beginning of the twentieth century. And the ideal of a feminine mystique combining domestic joy and duty emerged after World War II (Chafe, 1972; Cowan, 1983; Degler, 1980; Kessler-Harris, 1982; Tilly and Scott, 1978; Zaretsky, 1976).

The theme that reflected the black domestic worker of the 1950 s was a woman transcending, refusing, fighting back, and asserting herself over and against monumental obstacles. Both in the North and South, the demand for domestic workers remained steady in the 1950s. As many white women entered librarian, secretarial, nursing and teaching jobs, black domestic workers were continuously being hired. They further stated that Jim Crow was under attack from several standpoints in the $1950 \mathrm{~s}$, facilitating an 
increase in opportunities to black women to control their labor. The rising visibility of domestic work coincided with the steady deterioration of Jim Crow.

\section{Activism}

By the 1960 s, nearly ninety percent of black women in the South worked as domestic workers. The oppressive objectivity that southern black domestic workers were subjected to was a discursive, systematic and pervasive mistreatment based on their race and occupation. As members of a social, political and economically disadvantaged group, their mistreatment was normalized by the dominant culture. Observers consistently noted that southern black women formed the backbone of the movement and took the lead in the struggle for dignity. From their participation as bus-boycotters of Montgomery to their hosting of visiting Mississippi SNCC workers, domestic workers assumed responsibility for the care and protection of their larger families. They displayed courage daily, far from the glory and glamour of the civil rights hierarchy, while working in the homes of whites and sometimes being arrested and jailed.

Similarly to student Freedom Riders, many black southern domestic workers were imprisoned due to their efforts to register to vote, resistance to riding in the back seats of buses, or for picketing segregated businesses. For some of them, being jailed for a political crime was more of a reprieve than punishment. It allowed them time not only for physical and emotional rejuvenation, but also afforded them an opportunity to recruit and educate other black women (Hogan, 2007; Reed, 2005). Brown and Stentiford (2008) wrote that black domestic workers during this era were known for their community and political activism to such an extent that the postwar Civil Rights 
Movement was directly informed by the legacy of domestic service.

The neighborhoods of many domestic workers served as launching pads for informal and formal collective action and mutual support, to meet the goals of mobilizing resources for daily sustenance and fighting against oppressive working and living conditions. Refusing to leave their fates entirely in the hands of Jim Crow, black domestics and other black working class women in Atlanta, for instance, attacked persistent social and economic problems from every angle.

In their churches, domestic workers established food and clothing banks as well as networking sessions for those seeking employment. They assisted in remedying the social imbalances produced by capitalism and created alternative survival and coping mechanisms. Activism and resistance were characteristics often attributed to domestic workers which they exercised due to the segregated and unjust societies in which they lived (Jackson \& Weidman, 2004; Jaspin, 2007; Jones, 2010; Smith, 1996).

According to a study by Boris and Nadasen (2010), the organizational skills of domestic workers can be described as stellar. For example, one of the most impressive strikes by domestic workers was in Atlanta in 1881. Domestic workers formed a trade organization called the Washing Society. These workers went door-to-door, spreading their protest of menial pay. Because nearly every white household relied on a black woman to do its laundry, the strike affected the entire city. This began a domino effect as other household laborers began demanding higher wages as well. The women prevailed in raising their rates. In looking at other forms of resistance, Boris and Nadasen state that most acts of resistance by domestic workers were informal. For instance, a large portion of domestic workers refused to live-in while others refused to work Sundays. 


\section{Mobilization \& Unionism}

Long-term reform has remained elusive to domestic workers because of their limited power to shape state policy. The scattering of domestic laborers among private employer residences has precluded workplace forms of mobilization. By necessity, workers such as cooks, nannies, housekeepers, and elder care providers in private homes have been excluded from the collective bargaining table and most labor standards have turned to coalition-building and political strategies to gain respect, recognition, safety from violence, and living wages. However, there were successful attempts by trade union labor organizations. For example, The National Domestic Workers Union (NDWU) was founded in Atlanta in 1968 by Dorothy Bolden, who wanted to set standards for salaries and benefits received by women who were employed as domestic workers.

Under the direction of Bolden, the NDWU began an employment service, a Homemaking Skills program, and a Maids Honor Day to bring attention to the importance of work that was long seen as menial and unworthy of adequate pay and recognition. Ms. Bolden also served as the president of NDWU. Bolden's pioneering development of organizations that appeal to social justice causes, fair wages and health benefits birthed today's plethora of coalitions and organizations that support domestic workers such as the Domestic Workers United and the California Domestic Workers (Clark-Lewis, 1994; Mjagkij, 2001; Smith, 1996).

In the early twentieth century, domestic worker resistance continued. Refusing to live-in, black migrants to the urban North transformed domestic service. Although five or six dollars a week was considered a decent salary, household employment maintained its association with servitude. Some relatively short-lived unions managed to develop, aided 
by the International Workers of the World (IWW) in Denver, black clubwomen in Washington DC, and the Hotel and Restaurant Employees Union in the South. Unfortunately, with the ideology of white hegemony and racist political and social circumstances, sustaining organizations among low-waged employees proved to be a difficult task (Denning, 1998; Mjagkij, 2001). Most groups, including those connected to the Urban League's Negro Workers' Councils, remained associations or clubs.

Unions failed to sustain themselves and the American Federation of Labor's (AFL) refused to recognize domestic labor as skilled or possessing craft attributes. Large labor and trade unions focused more on industrial and manufacturing and never considered the home a workplace. Subsequently, organizers of domestics, thus, turned to the YWCA model, which brought domestic workers together for a number of educational and recreational programs and then encouraged them to act. This model offered a more appropriate form for advancement than traditional trade unions in so far as it gathered together scattered laborers and created bonds of solidarity through non-workplace activities.

Non-government organizations (NGOs) organizing, then, shifted strategy from union recognition and collective bargaining, which was difficult given the thousands of individual employers, to state legislators and lobbyists. This strategy was not very successful as wives of legislators and lobbyists seemed more concerned about protecting their homes from filth and disease that black domestic workers might bring inside than with the wages and hours of domestic workers (Cooper, 1997; May, 2011).

For much of the twentieth century in the United States, black women continued to perform household labor, though the tasks varied by region, class, and employer needs. 
Because homes are thought of as private and those within as hidden from view, the location of household labor conventionally appeared as a roadblock to collective action. Many live-in workers are separated not only from other workers, but from friends and family as well. Historically, reports have been made that some employers have held women against their will, as the National Association for the Advancement of Colored People (NAACP) reported during an investigation into the practices of Long Island employment agencies that brought women there from Florida in the early 1950s. Several cases a year are now being tried under the Trafficking Victims Protection Act of 2000 (Ehrenreich and Hochschild, 2000; Glenn, 2002; Palmer, 1989; Storrs, 2006; Sutherland, 1981).

While some have celebrated home-care unionization, the structure of the industry has meant limited improvements in wages, benefits, and working conditions. Unionism had reached only those domestic laborers who come under public payment systems because these workers can be found either through social welfare determinations regarding clients or third-party vendors who hold contracts with the state. Reliance on the state has its downside: when state budgets fall, officials seek to cut both reimbursement rates to agencies with contracts to provide home care and social assistance, which pays for the service, to receivers of such labor, mostly poor elderly women and disabled people (Boris and Klein, 2007; Greenhouse, 2008; McClendon, 1972).

\section{$\underline{\text { Discrimination }}$}

There is limited insight into relationships between African-American domestics and white female employees for the period following World War II. Susan Tucker (1987) 
however, has used oral histories, starting with the 1950s, to describe domestic life of Southern black domestic workers and white employers. Tucker noted that black domestic workers in the segregated South wore uniforms, worked long hours, and had very little education.

While conducting her own interviews in Norfolk, Virginia, Barnes (1993) found that white female employers often depended on black domestics for companionship. Nevertheless, a majority of the 240 black women studied in Norfolk and surrounding cities preferred working for white males rather than white females. Barnes also reported that positive interpersonal relations in the working environment with employers were important to the domestic worker. She stated that domestic workers used a variety of strategies to attempt accomplishing this feat. For example, they agreed to using an outdoor toilet; refused to complain about their working conditions (such as a stove that did not work properly); showed deference or respect by, using courtesy titles for their employers; complied with housework requests; allowed the white female employer to take the lead in conversation and housework assignments; kept secret the sexual advances of the white female employer's husband; and remained competent in their work.

Workers not only took on the burdens of household maintenance but also those of family nurturing for white middle-class women (Anderson, 2000). They did both the dirty, heavy manual labor of cleaning and laundering and the emotional work of caring for children. By relieving their white female employees of the most onerous and timeconsuming household tasks, black women freed white women to perform supervisory tasks, leisure and cultural activities, (activities that black women were not allowed to enjoy) or, more rarely during this period, careers. Ironically, many white women fulfilled 
society's expectation of feminine domesticity only through the domestic labor of their servants, who were black women (Dal la Costa and James, 1972).

On the other hand, providing domestic labor for a white family meant not being able to perform the same duties for her own family. While most European immigrant domestic workers were single young women who left service upon marriage, many black women were wives and mothers. For them, domestic service was often a lifelong occupation. The social norm that glorified the domesticity of white women did not extend to black women. While the predominant social norm or code of domesticity may have constrained white women, it placed black women in a completely untenable position. Forced to work outside the home, few black women were able to devote as much time to their own families as the dominant gender ideology demanded (Mahnaz, 1999). Struggling to take care of their families in substandard housing and on inadequate wages, black women were often judged deficient as wives and mothers according to white middle-class standards.

\section{Conclusion}

Today, domestic work is part of a growing service sector. Documented by scholars such as Chang (2000), the reliance on domestic service over the past decade has become global as two-parent families with both adults working seek out assistance for housekeeping and childcare. These workers face many of the typical problems historically encountered by black domestic workers. Attempts to organize compounded with exploitation and abuse is not uncommon. Whereas Dorothy Bolden lingered at bus stops to find Atlanta's domestic workers, today organizers go to playgrounds and ethnic 
stores, hoping to find domestic workers. As stated by Jones (1985) the struggles between black women and the whites who sought to profit from their labor has permeated throughout American history. Black women were and remain a reliable source of cheap labor.

Today, some groups of domestic workers are still excluded from the right to bargain collectively under the National Labors Reaction Act (NLRA). Like farm workers, they were originally excluded from minimum wage and overtime laws in an effort to win Southern votes in favor of New Deal legislation (Gordon, 2005). As a result, today home health care workers are still excluded from both the minimum wage and overtime laws, and all live-in domestic workers are excluded from overtime pay under federal law. At least 1.8 million workers work as domestic workers in American homes. Domestic work includes at least three occupations: cleaning, child care, and caring for the elderly and the disabled. Most of these workers (95 percent) are female, foreign born and/or persons of color (Cobble, 2004; Poo and Tang, 2004).

In 2005 , the wages for in-home workers were one-half the national median income. A survey of workers in New York found that forty-one percent of these workers earn low wages, with an additional 26 percent earning below poverty-level wages. Half of the workers have overtime hours each week, with a substantial number working 50-60 hours per week. Of these, sixty-seven percent do not receive overtime pay (Milkman, 2006; Tait, 2005).

In 2007, domestic workers in the San Francisco Bay Area found that 63 percent of domestic workers consider their jobs hazardous; citing concentrated exposure to toxic cleaning chemicals and human contagions, risk of injury from cleaning high or difficult 
to reach places, and heavy lifting, yet there are no health and safety protections for domestic workers. Nationally, just thirteen percent of in-home workers who employed at least half time, year round get health insurance provided by their employers (Das Gupta, 2008).

Domestic work has become a more sophisticated and organized employment process. The work encompasses at least two forms of work: direct hire by householders and referrals through agencies, with some of the work occurring outside the home (Parrenas, 2001). Some workers work for one employer, while others piece together many jobs under multiple employers. Industry differences also exist between the private pay market and the government-subsidized market, which supports some child care and home health care work (Smith, 2011).

A recent survey of low-wage workers in three major US cities-New York, Chicago and Los Angeles-found that 41 percent of workers in private households had suffered violations of the minimum-wage law in the week prior to the survey. Child care workers endured the highest rate of violations of their rights, at 66.3 percent. Twentynine-and-a-half percent of maids and housekeepers were not paid the minimum wage, and 17.5 percent of home health care workers endured minimum-wage violations. These workers also suffered high rates of overtime violations, with more than 90 percent of child care workers and 82.7 percent of home health care workers experiencing violations (Boris and Nadasen, 2010).

Although it is impossible to calculate how many domestic workers in the United States are subject to forms of slavery and servitude, some experts predict that approximately one-third of 15,000 to 20,000 victims of labor trafficking in the United 
States annually are migrant domestic servants (Fine, 2007). It was also reported, in 2008, a pending prosecution on Long Island of the employers of two Indonesian women. The employers allegedly made the women sleep in closets of their multi-million-dollar home, forced them to work day and night, deprived them of food, threatened, tortured and beat them, and forbade them to leave the home. Four other recent cases involve the wife of a Saudi prince, who was convicted in Boston for keeping two house servants for three years in virtual slavery; two Wisconsin doctors, who held a Filipina woman as an indentured servant for 20 years; a Maryland couple, who kept a Brazilian woman in their home as a servant for 15 years, paying her nothing; and finally a California real estate agent who enslaved a Peruvian nanny in her home after luring her to the United States with false promises. In addition, many domestic workers who migrate with an agreement from their employer or through agencies live and work under virtual debt-bondage in order to pay back exorbitant fees they owe for the contract (DWU, 2008).

The exploration of societal factors and implications that pertain to domestic workers highlight the circumstances of the oppressive conditions that are perpetuated by a mixture of dominant societal views and practices. Although embedded within a structural context of three interlocking systems of oppression; racism, sexism, and classism, activists who were black domestic workers performed roles that by any standard would merit their being considered heroes and leaders of the movement. The use of oral history is significant in this research as it brings to light the perspectives of individuals who might not otherwise appear in the historical record. The domestic workers who participated in the Civil Rights Movement proved to be a formidable vice against racist socio-political policies in the U.S. Most of these women have remained 
anonymous, hidden, a category of invisible, unsung heroes of one of the most revolutionary periods of modern American history. 


\section{CHAPTER TWO: \\ BLACK DOMESTIC WORKERS IN THE CIVIL RIGHTS MOVEMENT}

The majority of existing research on modern social movement leadership has neglected the crucial roles of black women and presented the erroneous image that all of the women are white all of the blacks are men (Hull, Scott, and Smith, 1993). Yet scholarship and recollections all illustrate that, far from being apolitical or inconsequential, black women were crucial to the Civil Rights Movement; that their personal experiences were unique as well as political, and that black women's activism should be central to social movement scholarship (Barnett 1989/1993; Blumberg, 1990; Crawford, Rouse, and Woods 1990; Robinson, 1987).

This chapter aims to exam why the Civil Rights Movement was needed, what the role of women were at the time of its conception, and how these elements influenced the activism of black domestic workers. By looking at what fueled their participation, the lens through which they saw their predicament can be best viewed. Additionally, it is important to report the types of activist work produced by black women, and the risks they were willing to take to advance the Civil Rights Movement. 
The Civil Rights Movement

The Civil Rights Movement was an effort by blacks and whites in the mid-1950s to late 1960 s to achieve civil rights equal for blacks as those of whites, including equal opportunity in employment, housing, and education, as well as the right to vote, the right of equal access to public facilities, and the right to be free of racial discrimination. No social or political movement of the twentieth century has had as profound an effect on the legal and political institutions of the United States (Bloom, 1987; Klarman, 1994). This movement sought to restore to blacks the rights of citizenship guaranteed by the $14^{\text {th }}$ and $15^{\text {th }}$ Amendments, which had been eroded by segregationist Jim Crow Laws in the South. It fundamentally altered relations between the federal government and the states, as the federal government was forced many times to enforce its laws and protect the rights of black citizens (Fendrich, 1993).

The movement for racial equality in the United States, known as the Civil Rights Movement peaked in the 1950s and 1960s. Through nonviolent protest actions, it broke through the pattern of racial segregation to secure equal access to and opportunities for the basic privileges and rights of U.S. citizenship to African Americans. The roles of black domestic workers in advancing the civil rights of blacks was exemplary, and has been nearly absent in scholarly works. Subsequently, as depicted in the film The Help, their personal lives have been examined to some extent to a lesser degree than their work experience and their activism and resistance. As many people are aware of the contributions made by Fannie Lou Hamer, a sharecropper and domestic worker from Mississippi who challenged and helped gain voting rights for black Mississippians, there are many others like her whose contributions have made a positive impact on the lives of 
all African Americans (Bracey, 2011; Lee, 2000; Mitchell, 2006). They continued to stand up against racial injustices and segregation.

Racial segregation is the separation, either by law or by action, of people of different races in all manner of daily activities, such as the use of public facilities and public transportation. It is a form of institutional racism.

Segregation was used in the past as a deliberate tactic to institutionalize group identity (Collins and Williams, 1999). Racial classifications are almost always linked to forms of unjust economic and social inequality, domination, and exclusion, as well as to belief systems that assign superior and inferior statuses and attributes according to race. As a sociological generalization, racial classifications become salient in people's lives primarily to the extent that they are linked to forms of socioeconomic inequality and oppression.

Despite race being a social construct, historically it was used, and continues to be used, as a destructive and deliberate action in American culture. Although the general boundaries of race relations had been drawn after the abolishment of slavery, racial segregation began approximately a decade after the Civil War (Cohen, 1991; Smith, 2002). Segregation entailed a symbolic as well as material division of social space (Massey, 1993; Massey, White and Phua, 1996). While no longer considered acceptable in most countries, racial segregation still exists in many communities (Musterd, 2001; Phillips, 2007).

According to Hunter (1998) the rules of segregation became increasingly petty after the turn of the century. Blacks and whites could not touch the same bible in court rooms or drink from the same fountains. Southern whites stripped away voting rights and 
other public rights of equal citizenship, and racial subordination was continually recreated in everyday routine actions (Drake, 1987; Heneghan, 2003; Steinberg, 1998). Segregation operated as a highly adaptable way of socially organizing a disfranchised group within American society, and discriminatory laws instilled and validated segregation (Kuznicki, 2009; Lipsitz, 1995). The issue of segregation was just not one of the grievances that existed for African-Americans, but it was one that was conducive to movement activity. Activists used formal constitutional rights to challenge existing social and political systems. Jo Freeman's theory of "spontaneous generation" can be applied to Civil Rights Movement formation because the grievances of African Americans existed and the sociopolitical structure was more willing to address America's racial problem during this era than before.

Although exact numbers are not available, it is clear from numerous accounts of the Civil Rights Movement that women formed a substantial portion of the participants both individually and as organizations (Barnett, 1993; Crawford, 1987; Giddings, 1984; McAdam, 1988). This has been obvious due to the numerous studies documented regarding women's involvement in grassroots mobilization (Bookman and Morgen, 1988; Chafetz and Dworkin, 1986; Kaplan, 1982; McCourt, 1977; Naples, 1992; West and Blumberg, 1990). What has not been provided are systematic analyses of the patterns of their participation and the ways in which constructs of exclusion, such as gender, shaped the development of leadership as well as the organization of social movements. Gender provided a construct of exclusion that helped to develop a strong grassroots tier of leadership that served as a critical bridge between the formal organization and adherents and potential constituents. 
While previous attempts had been made to enact a Movement in northern cities and rural towns, the mobilization of such a movement was less difficult in larger cities where student participation and community involvement was greater (Lawson, Payne and Patterson, 1998). The direct action efforts in the larger cities in the South were also visible to the media. For example, violent reprisals especially in rural areas of the South were less likely to receive such attention. Moreover, in rural areas and in small towns, outsiders were more visible and the contacts among organizations more tenuous. Outsiders were not trusted by these populations, and many wanted no part in stirring up trouble. Mobilization of these sectors required specific recruitment tactics that built upon trust and interpersonal community ties. These masses, no matter how inspired by the charisma of the movement leaders or impressed by the financial resources of the organizations, would not risk their lives. Although network ties among ministers in large cities provided a powerful resource for mobilization, this was not always the case in rural communities or smaller cities (Barnett, 1993; Hall and Spruill, 2005; Hogan, 2007).

Anecdotal and systematic evidence has documented the influence of social movements in the 1960s. Women who were young adults during this era reported that they found the movement meaningful and influential, and found the mobilizing and organizational efforts of black women to be inspiring (Evans, 1979; Franz, 1994; Giddings, 1984). Black women specifically, accounted for the mass majority of the population of resistors to racism and activists of social change.

There is undoubtedly a connection between resistance and social change. The complexities of resistance and the social and interactional nature of resistance are obvious sociological issues. These issues spawn debates about power and control and the 
relationship between individuals and social context. Some scholars are focusing more research on the study of resistance in order to debunk the idea that ordinary people are taken advantage of by the powerful and to show that people can think for themselves (Fisher \& Davis, 1993; McCann \& March, 1996). One of the greatest examples of this in United States history is the survival and continuation of African-American life (Billingsley, 1992; Martin \& Martin, 2002).

After experiencing some of the most brutal forms of injustice and dehumanization in U.S. history, African Americans continue to survive and function with remarkable resiliency. However, because people of European ancestry have had more power relative to other racial groups, their experiences and interpretations have dominated the American socio- cultural landscape (Ani, 1994; Asante, 1999; Hacker,1992; Turner, Singleton,\& Musick, 1984). To a considerable degree, the persistent opposition to African American survival and advancement has compelled African Americans to coalesce and work toward common goals of racial equality.

\section{Role of Women}

Some scholars have begun to examine the different experiences of men and women activists (Lawson and Barton, 1980; Payne, 1989). McAdam (1992) for example, has discussed the importance of deconstructing the experiences of Movement participants. He found significant gender differences in the recruitment processes of white participants in the Student Nonviolent Coordinating Committee, a civil rights movement organization. Such a study provides support for the notion that participants are not a monolithic group. Thus, it is equally important to analyze the different movement 
experiences as determined by one's race, class, and gender.

Robnett (1997) suggests that African American women were constrained by gender and therefore the primary avenue of leadership open to them was one of a grassroots leadership that served as a critical bridge between the formal organization and adherents and potential constituents. Early works of the Civil Rights Movement focused mainly on the roles of visible leaders, the men, and paid little attention to the role of women. However, scholarship such as studies by Giddings (1984) and Crawford, Rouse, and Woods (1990) brought to the forefront the work done by Black women in the movement. Charles Payne $(1990 ; 1995)$, in his study of the Greenwood movement in the Delta region of Mississippi, found an over-participation of Black women, meaning that the Black women were more politically active than the Black men. Payne examines the possible causes for this and in doing so points out the necessary organizing skills Black women provided to the movement.

The invisibility of modern black women leaders and activists is in part a result of gender, race, and class biases prevalent in both the social movement literature and feminist scholarship. Social movement scholarship has focused almost exclusively on great men and elites as movement leaders (Jenkins and Perrow, 1977; Oberschall, 1981; Rose and Grenya, 1984). Black women in communities and organizations throughout the South and other regions were struggling during a time that some feminist scholars initially labeled the cessation phase for women's activism (Ferree and Hess, 1985; Rupp and Taylor, 1987). They were assumed to be uninvolved in feminist organizations or unconcerned about women's rights.

However, Lerner (1979) has pointed out that women's liberation means different 
things to different women. For many of them, they simply wanted to be free to care for their own homes and their own children while being supported by their employed black men. The critics of the prevailing research on black women have pointed out three major biases: (1) a negative problem-oriented image that stereotypically connected black women with various pathologies within the family, such as female-headedness, illegitimacy, teen pregnancy, poverty, and welfarism (Barnett, Robinson, and Bailey 1984; Collins 1997); (2) a middle-class orientation that excluded, ignored, or made inconsequential the experiences of poor and working-class women, a large percentage of whom were black (Bookman and Morgen, 1988); and (3) an apolitical, non-leadership image of black and poor women as political passivists or as followers and organizers, rarely as movement leaders (Barnett, 1989).

In a research study by Irons (1998) interviews were conducted of black women who were participants of the Civil Rights Movement in Mississippi. She identified three types of women's participation in the Civil Rights Movement and the ways these varied by race: (1) high-risk activism, (2) low-risk institutional activism, and (3) activist mothering and women's work.

High-risk activism was seen as anticipated dangers whether legal, social, physical or financial (McAdam, 1986; Roediger, 1991; Saxton, 1990). Some of the high-risks taken by black women described by Iron included being beaten by police, hiding pictures of one's family to keep them from harm, or taking alternate routes home from meetings to protect personal safety. Euvester Simpson Morris who was interviewed by Iron reported that while returning from a citizenship school in South Carolina with Fannie Lou Hamer, Annell Ponder and others, their bus made a restroom stop in Winona, Mississippi. The 
entrance of the colored restroom was blocked by whites. When they walked to the white's restroom they were told they could not enter. Once Ponder began writing down the license plate of one of the police officers, the women were arrested, taken to jail where they remained for five days, and most of them were severely beaten. Iron emphasizes that Black women had more to gain by participating and thereby more willing to risk more.

Gore (2010) explores the connections between the African American women radicals and the black freedom movement of the 1960s. She notes that many women were forced to find new venues of employment as they became activists. They became involved in social movements through their organizations, such as the Negro Women's Action Committee, which supported the 1960 student sit-ins at lunch counters throughout the South. In 1961, they helped launch the quarterly journal Freedomways, then worked on programs to end racism in the New York City public schools and to promote international ties with Communist countries and decolonizing nations, and supported the Free Angela Davis campaign and the Free Joan Little movement. Gore states that her aim was to analyze the actions of black women radicals and their collective experiences into the history of postwar radicalism by centering their insights and documenting their contributions to sustaining a black left politics well into the 1970 s. Gore also demonstrated an excavation of crucial foundations of the more familiar civil rights stories of the Montgomery bus boycott and the Woolworth's sit-ins that are already the subject of so many studies. The events she chronicles, with women front and center, serve as a reminder that such high-profile achievements have a long, complex history.

Numerous studies of women's involvement in grassroots mobilization (Andreas, 
1985; Barrios, 1978; Bookman and Morgen, 1988; Fainstein and Fainstein, 1974;

Jayawardena, 1986; McCourt, 1977; Sacks, 1988; Sacks and Remy, 1984; Thomis and Grimmett, 1982) suggest that women, even when they outnumbered men in participation as they did in the Civil Rights Movement, often initiated and led movement activities and later receded into the background (Davis, 1982; Dunavyevskaya, 1985; Lawson and Barton, 1980; West and Blumberg, 1990).

Many white women who were involved in the Movement in Mississippi were low-risk participants (Jenkins, 1983; McAdam, 1986). Iron describes low-risk participators as those who were involved working with organizations which often had religious affiliation, and offered white women an avenue to contribute without placing their lives at risk. This form of participation was open to white middle-class women who could have engaged in high-risk activism, but would have been in jeopardy of losing their economic, social, and political status in Mississippi society. Two of these women, interviewed by Iron, shared their experiences. Barbara Barnes, president of Jackson, Mississippi operations of the YWCA in 1964, helped to mediate the integration of the Jackson YWCA in 1968. She reported that because of her efforts to promote racial equality in her community, she was ostracized by her Sunday School class. Jane Schutt was a member of Mississippi's advisory committee to the United States Civil Rights Commission. As such, she traveled the state listening to complaints from whites who felt they would lose property value if blacks were allowed in their communities. Once it became public that she was Chair of the committee, her husband's job was threatened, and a cross was burned in her yard. 
As stated by Irons, women brought different skills than men to the Civil Rights Movement. Activist mothering or women's work were skills relating to maternalism, nurturance, and domesticity. As such, Irons argues that the contributions made by women to the Movement have been devalued when their participation was confined to the domestic sphere.

\section{Black Domestic Workers}

According to Jones, (2010), domestic workers were an unpaid community of organizers who helped mobilize, coordinate and inspire boycotters and demonstrators. The willingness of domestic workers to house visiting student freedom riders, to make protest signs, and present as the largest group of bus boycotters represented the recognition of formal constitutional rights. The American society was forced to examine its racist history. This actualization in conjunction with the larger society's willingness to address codified institutional racism allowed the Movement to take shape (Freeman, 1983; Melucci, 1989).

The behind-the-scenes leadership was the only one available to domestic workers. Consequently these women contributed significantly to the extraordinary nature of the grassroots leadership within the Movement. They worked at canvassing in local communities and, on a day-to-day basis, were able to make decisions within the local community. Canvassing included (1) seeing what was on people's minds-what kinds of things they would like to see done; (2) getting individuals to register to vote; and (3) recruiting individuals for local demonstrations.

Domestic workers organized themselves by meeting in their homes and churches. They created a grapevine of sorts to communicate information among each other 
regarding Movement activities. Some assisted with voter registration and recruitment while others challenged Jim Crow laws by walking into whites-only restaurants or by carrying picket signs outside the doors of segregated establishments. Others arranged car pools and sold cakes and pies to raise money for alternate transportation (Collier-Thomas \& Franklin, 2000; Dudziak, 2000). The participation of the domestic workers to the Movement was their way of displaying resistance to racism.

Physical resistance such as refusing to ride buses because of discriminatory practices was a major role of activism for domestic workers. In Montgomery, Alabama, for example, it became a collective practice as others in black communities throughout the U.S. joined, organized and participated in what led to the infamous Montgomery Bus Boycott which lasted more than a year. Other acts of physical resistance included working slowly when performing household chores, and feigning sickness in order to spend time participating in Movement activities (Feagin, 1991; Floyd, 1994).

The visibility of this resistant act helped the Movement gain both financial and physical support. With the help of television, the activism displayed by protesters was played out for the world to witness. According to Kelley (1985) unlike the popular image of Rosa Parks' quiet resistance, most black women's opposition to Jim Crow laws tended to be profane and militant. He states that there were numerous episodes of black women sitting in the white section on buses, fighting with white passengers, and arguing with drivers. The women would finally move to the back of the bus, receive a refund for their fare and leave on their own accord, or get arrested and taken to jail. He concludes that while some black women's actions became violent or profane, gender differences in power relations and occupation did shape black women's resistance. However, domestic 
workers were in a unique position to contest racist practices on public transportation as they were the largest population of riders. Consequently, only two weeks into the bus boycott, the transportation system of Montgomery was already feeling the effects. According to a New York Times article entitled Negroes' Boycott Cripples Bus Line, the fares had been raised by fifty percent to help cover its losses.

When McGrew (2006), interviewed Johnnie Carr, a former domestic worker from Montgomery, Alabama, and childhood friend of Rosa Parks, she stated that due to segregation laws, she was not allowed to take her children to the park that was directly across from her home. She added that attempting to explain to her children why they could not play there was one of the most difficult things she has had to do. Like Ms. Carr, many domestic workers were motivated by their desires to improve conditions for their children. Ms. Carr later worked for the NAACP and Montgomery Improvement Association, which organized the Montgomery Bus Boycott.

Observers consistently noted that southern black women formed the 'backbone" of the movement and took the lead in the struggle for dignity. From their participation as bus-boycotters of Montgomery to their hosting of Mississippi SNCC workers, domestic workers assumed responsibility for the care and protection of their larger families. They displayed courage daily, far from the glory and glamour of the civil rights hierarchy, while working in the homes of whites and sometimes being arrested and jailed. Similar to student Freedom Riders, many black southern domestic workers were imprisoned due to their efforts to register to vote, resistance to riding in the back seats of buses, or for picketing segregated businesses (Denning, 1998; Joseph, 2006; Piven and Cloward, 1979). 
The black church was a chief vehicle of protest, and a regular meeting place for domestic workers to organize and recruit (Lovett, 2005). The black church had a mass base and served as the main repository of Black culture. It proved to be capable of generating, sustaining, and culturally energizing large volumes of protest. Its music and form of worship connected the masses to its protest tradition stemming back to the days of slavery (Calhoun-Brown, 2000; Findlay, 1990). The social power of the black minister stemmed from his personal persuasiveness and his considerable control over the collective resources of the church (Brown, 2008; Merelman, 1994; Morris, 1984). As a result, the church supplied the Civil Rights Movement with risk-taking individuals and the collection of resources. Economic independence also allowed some black ministers the freedom to share political beliefs with their congregations.

Some ministers encouraged political activism while others feared white repercussions against such political involvement (Lincoln and Mamiya, 1990). Since many Civil Rights organizations connected with the black community through churches, the political consciousness of the Movement was propagated via the church. Additionally, black pastors have traditionally been men. As a result, access to the leadership and power of the black minister was denied to black women, who served as ushers, choir members, and secretaries within the church's formal hierarchy. Because the church was a major source of Movement leadership potential, its gendered church positions indirectly attempted to hinder the potential leadership of black women in the Movement from the very beginning (Fendrich, 1993; Joseph, 2006; Kerber, 1998). Lovett (2005) adds that the church also served as a refuge for many of the 
domestic workers who worked during the day under rigid and demeaning conditions, and then volunteered their time and talents to the Movement. Also in churches, domestic workers established food and clothing banks and networking sessions for those seeking employment. They doubled their coping efforts to substitute the public services that were denied blacks by white establishments. They assisted in remedying the social imbalances produced by industrial capitalism (Hunter, 1998).

Hogan (2007) states that Mississippi summer volunteers wrote letters home to friends and relatives with the descriptions of feasts that were prepared for them by domestic workers. Similarly, Wekker contends that Sugrue (2008) reported that civil rights workers stated that they were able to withstand overwhelming opposition because of the image of the black working woman.

Domestic workers accepted the justifications for nonviolence, but were prone to express their anger in words (Bermanzohn, 2000: Garcia, 1994). In contrast, many white southerners resorted to physical or economic retaliation against peaceful demonstrators. In many southern cities whether demonstrations were held there nor not, southern vigilantes patrolled the streets with firearms. Some white physicians refused to deliver babies of mothers who were on the local white citizen's council blacklist, a list that contained the names of black women who were participating in the Movement (Evans, 1980; Hurt, 2003; Schramm-Pate and Jeffries, 2008).

The passing of the Title VII of the Civil Rights Act of 1964 demonstrated the impact of African American female workers. It outlawed discrimination in hiring based on race, color, religion, gender of national origin. It also established the Equal Employment Opportunity Commission (EEOC) (Belton, 2004). 
As a result of gendered societal roles, black domestic workers brought different skills than men to the Civil Rights Movement. These skills were related to maternalism, nurturance, and domesticity. Iron refers to Naples (1998) theory of activist mothering which includes not only the nurturing of those outside one's immediate kinship group but also general social mothering practices of the community. As an example, Iron tells the story of Aurelia Young, an African American woman who housed and fed students of the Freedom Rider movement in 1961 once they were released from jail. She also fed civil rights workers and attorneys in her home. Her work can be considered activist mothering, because she cared for children who were not her own, and she extended her mothering responsibilities to the civil rights community.

Domestic worker and interviewee Georgia Gilmore reported to Robnett (1997) that once her employer learned of her activism, she was fired from her job as a cook and blacklisted from other jobs in Montgomery. Subsequently, Gilmore began selling baked goods door-to-door, donating the funds to the Montgomery Improvement. Robnett redefines leadership, combating scholarship that has failed to see women's participation in the Civil Rights Movement as leadership. She demonstrates the importance of methods that do not define leadership on the basis of formal titles. Robnett argues that titles usually falter in encompassing the contributions made by black women in the Movement. Women without titles, who worked in the field, often had considerable autonomy to lead, and were recognized by their co-workers and those they mobilized as leaders. In addition, Robnett also states that women leaders in the community frequently recruited and mobilized male formal leaders. Though cultural and societal norms established some limitations on women's formal leadership, Robnett finds the lens of gender discrimination 
inadequate for analysis of women's roles.

Paid domestic laborers were treated simultaneously as invisible and as the personal property of their employer. In the minds of some employers, the racial makeup of the workforce-which encouraged employers to construct their employees as vastly different and inferior-justified low wages and poor working conditions. The othering of domestic workers reconciled for abusive employers their own sense of fairness and the inhumane treatment they mete out to workers (Sharpless, 2010). At the same time, the intimate nature of the work fostered a fiction of familiarity where employers claimed their household help as one of the family and used this claim to extract additional work without pay or to offer second-hand goods in lieu of pay. Although domestic workers may have been expected to fulfill familial responsibilities, they were rarely accorded familial rights—even such basic rights as sitting at the dinner table. Live-in workers in particular were often at the beck and call of their bosses, with little time to themselves and no clearly defined job description (Rothman, 1978).

For many employers, hiring domestic workers was not limited to hiring their services or their time-it was conflated with the purchasing of their very bodies. Placing black women's experiences at the center of analysis as well as interpretive frameworks that rely on intersectional paradigms helps to shed light on their experiences dealing with racism and sexism (Smith 2000, Palmer 1995).

Domestic workers worked alongside professional black women as well as college female students while participating as activists. Subsequently, domestic workers were educated by these women regarding Jim Crow laws and other race issues. As the professional and student women were being educated at places like the Highland Folk 
School, in many cases they would extend their newfound knowledge to the domestic workers. Founded in Sewanee, Tennessee in the 1930s, Highlander was a center of grassroots political activity and work toward social change. Focusing mainly on Appalachian white poverty and the formation of labor unions in the $1940 \mathrm{~s}$, the fight for desegregation and racial equality was added to Highlander's agenda in the early 1950s (Glen, 1996). Highlander opened its doors to students in 1953 by creating "Annual Highlander Folk School College Workshops" where students could come to discuss civil rights.

During the mid-1950s and throughout the Civil Rights Movement, the lives of domestic workers served as reminders to the preservation of racial distance. Their persistence to challenge the triple constraints of race, class, and gender did not permit adequate recognition of their efforts. 


\section{CHAPTER THREE:}

\section{BLACK FEMINISM: THE MOVEMENT \& THE THEORY}

\section{$\underline{\text { Introduction }}$}

According to Tarrow (1994), social movements act as collective challenges by people with common purposes and solidarity in sustained interaction with elites, opponents and authorities. In other words, social movements are mass, grass roots phenomena. They tend to happen when a significant number of people come to define their own troubles and problems, not in personal terms, but in more general social terms; where there is a common cause for all of their troubles, and when they think that the government can be moved to action on their behalf (Johnston and Klandermans, 1995; Klandermans, 1992; Taylor and Whittier, 1995). This is a rare combination of circumstances, thus social movements are difficult to organize and sustain. Movements often help those who are outside the mainstream to gain a hearing from the public and political decision makers (Andrews, 1997; 2001).

Social movements are not always unified on issues of strategy and tactics. They are generally made up of a core of activists, a wider circle of people from aggrieved group who are occasionally active, and a larger audience made up of the general 
population and political leaders (Tilly \& Wood, 2009). To be successful, social movements must be able to play to all three audiences; maintain the enthusiasm of activists; attract other activists and support from the aggrieved group; gain sympathy from the general public; and force a positive response from public officials (McAdam \& Snow, 2009; Meyer, 2006).

Many social movements have left their mark on American political life and have influenced the actions of government. Each movement has tried to achieve social change by acting outside the normal channels of government and politics, using what is known as collective action (Younts \& Mueller, 2001). While women were always participants of social movements, they are particularly important in this study of women in the Civil Rights Movement.

\section{Feminist \& Women's Movements}

A significant segment of feminist activists came to recognize and understand their own oppression, as well as to develop important organizing skills through their participation in efforts for racial justice (Breines, 2007; Guy-Sheftall, 1995). Economic equality was also a goal of feminist movements from the 1960 s onward. Unlike many women's movements earlier in the century, which had often favored protective labor legislation for women, the new feminist organizations emphasized gender equality in the workplace (Joseph \& Lewis, 1999).

From the late 1960 s into the 1980 s, there was a vibrant Women's Movement in the United States. Culturally influential and politically powerful, the movement included national organizations, as well as grassroots projects and the Equal Rights Amendment 
(ERA) (White, Travis \& White, 2000). The women's movement was also made up of organizing projects in the professions, unions, government, and other institutions. The movement brought about major changes in the lives of many women, and also in everyday life in the United States (Newman, 1999). It opened to women professions and blue-collar jobs that previously had been reserved for men. It began transforming the portrayal of women by the media. It introduced the demand for women's equality into organized religion, sports, politics, and many other arenas and institutions. As a result, the gender balance of leadership began to change. The women's movement initiated dialogue publicly on issues that were once deemed private and personal by framing inequality and oppression in family and personal relations (Cheek \& Briggs, 1982). Despite their large number of organizations and successful reform efforts, black women were largely excluded from white women's reform organizations, suffrage associations as well as women's Christian groups such as the YWCA (McClaurin, 2001). In addition, in their reform efforts, white women were often culturally or racially insensitive, attempting to impose white middle class cultural values on black women.

White feminists defined gender as the principal source of their exclusion from full participation in American life; black women were forced to confront the interplay between racism and sexism and to figure out how to make black men think about gender issues while making white women think about racial issues. The call by white feminists for unity and solidarity was based on their assumption that women constituted a genderbased class or caste that was unified by common oppression. Many black women had difficulty seeing white women as their feminist sisters; in the eyes of many African Americans, after all, white women were as much the oppressor as white men. Bambara 
(1970) argued the non-existence of relevancy of truths and experiences of white women to black women. She argued that the priorities are not the same, only the concerns and methods.

\section{Black Feminist Movement}

The Black Feminist Movement grew out of, and in response to, the Black Liberation Movement and the Women's Movement. In an effort to meet the needs of black women who felt they were being racially oppressed in the Women's Movement and sexually oppressed in the Black Liberation Movement, the Black Feminist Movement was formed (Springer, 2002). All too often, black was equated with black men and woman was equated with white women (Hull, Scott and Smith, 1993). As a result, black women were an invisible group whose existence and needs were ignored. The purpose of the movement was to develop theory which could adequately address the way race, gender, and class were interconnected in their lives and to take action to stop racist, sexist, and classist discrimination. According to Hudson-Weems (1992), the term feminism as defined and used by European Americans did not portray the reality of African-American women and their level of struggle.

Faced with the sexism of black men and the racism of white women, black women in their respective movements had two choices: they could remain in the movements and try to educate non-black or non-female comrades about their needs, or they could form a movement of their own (Beale, 1970; Cheek, 1982). Although noble in its intent, black women did not feel the first alternative was a viable or feasible option. While black men needed to be educated about the effects of sexism and white women 
about the effects of racism on black women's lives, as noted by Hull, Scott and Smith, (1993) it was not solely the responsibility of black women to educate them.

Having decided to form a movement of their own, black women needed to define the goals of the Black Feminist Movement and to determine its focus. Several authors have put forth definitions of the Black Feminist Movement. Among the most notable are Alice Walker's definition which she coined womanist. According to Hudson-Weems (1994) this term signified an inclusion of race and class issues in feminism, and served as an alternative to and an expansion of the term feminist. The Combahee River Collective, whose name is taken from the Combahee River Raid of June 1863 which was led by Harriet Tubman and freed hundreds of slaves. As explained by Smith (2000) The Combahee River Collective Statement defined black feminism as a logical political movement to combat the multiple and simultaneous oppression that all women of color experience. According to the Collective, the genesis of contemporary black feminism involves an affirmation of its origins in the historical reality of African-American women's continuous struggle for survival and liberation. It was important for black feminism to address the ways that racism, sexism, classism and heterosexism all worked to perpetuate each other.

Black feminist writings began focusing on developing theories which would address the simultaneity of racism, sexism, and classism in their lives. In addition, the audience of these writings was to be black women, rather than white feminists or black male activists. Black women needed to develop a critical, feminist consciousness and begin a dialogue which directly addressed their experiences and connected them to a larger political system (hooks, 1984). 
The effectiveness of the movement, however, has not been uniform in the white feminist and black communities (Meyers, 2004). The rhetoric of current black liberation movements still fails to adequately address issues which affect black women. Awareness of sexism has increased within the black academic community but the popular culture (especially that which primarily involves black men, such as the rap music industry) continues to be extremely sexist and misogynist (Kitwana, 2002: Morgan, 1999).

The black feminist movement is faced with several challenges. As explained by Collins (2000) and Warhol-Down and Herndl (1989), the movement must find ways to broaden support among black and third world women. Education about the true nature and goal of the movement as well as resources and strategies for change must reach the women who have little or no access to the movement. In addition, Smith (2000), Bullard (2000) add there is a need for the development of mentor relationships between black women scholar/activists and young black students, both female and male. Individual struggle must be connected with a larger feminist movement to effect change, and so that new black feminists need not reinvent theory or search again for history that was never recorded. Springer (2002) and Morgan (1999) argue there is also a need to develop black male subjectivity to address black women as the primary audience of theoretical and critical black feminism. Black women and men need to develop a critical style which encourages further dialogue and development of ideas rather than dismissing or silencing new black feminist voices. Kitwana (2002) stresses that respect for fellow black women must be developed and guarded in spite of the sexist, racist, and classist ideologies of American society. Differences among black women must be acknowledged and affirmed, rather than ignored. 
Finally, as noted by Gardiner (2002) alliances must be strengthened between the black feminist movement and its parent movements. The black feminist movement must hold the current male-dominated black liberation movement accountable for its sexism and at the same time work with the movement to end the oppression of black people. As well, there must be a working dialogue between the white-dominated feminist movement and the black feminist movement to continue to develop perspectives, theory and action which strives toward ending sexism.

\section{Black Feminist Perspective}

A black feminist perspective is necessary in order to understand the complexity of the struggles which black women face. Drawing on this, black feminist have developed perspectives which recognize the constraints of a racially structured patriarchal capitalistic society (Bhavani, 1986). The emphasis on the pervasiveness of racism in economic, social, and political institutions through which black women's and black men's oppression is manifested (Bran, 1985). The inclusion of men in a black feminist perspective is based on the realization that the liberation of women through challenges to patriarchal structures cannot be successful unless all repressive ideologies are eradicated. Black women have added to the potential power of feminism as they have explored wider collective struggles against imperialism and racism (hooks, 1984; 1989; Hull, 1982).

Black feminist thought consists of ideas produced by black women that clarify a stand-point of and for black women. Several assumptions underlie this working definition. First, the definition suggests that it is impossible to separate the structure and thematic content of thought from the historical and material conditions shaping the lives 
of its producers (Berger and Luckmann 1966; Mannheim 1936). Therefore, while black feminist thought may be recorded by others, it is produced by black women.

Secondly, the definition assumes that black women possess a unique standpoint on, or perspective of, their experiences and that there will be certain commonalities of perception shared by black women as a group. Thirdly, while living life as black women may produce certain commonalities of outlook, the diversity of class, region, age, and sexual orientation shaping individual black women"s lives has resulted in different expressions of these common themes. Thus, universal themes included in the black women's standpoint may be experienced and expressed differently by distinct groups of African-American women.

Finally, the definition assumes that, while a black women's stand-point exists, its contours may not be clear to black women themselves. Therefore, one role for black female intellectuals is to produce facts and theories about the black female experience that will clarify a black woman's standpoint for black women. In other words, black feminist thought contains observations and interpretations about African-American womanhood that describe and explain different expressions of common themes.

\section{Conclusion}

Black women's decisiveness to self-define and the necessity for a black femalecentered analysis are significant for two reasons. First, defining and valuing one's consciousness of one's own self-defined standpoint in the face of images that foster a self-definition as the objectified other is an important way of resisting the dehumanization essential to systems of domination. The status of being the other implies 
being different from the assumed norm of white male behavior. Since black women have been denied the authority to challenge these definitions, this model consists of images that define black women as a negative other, the virtual antithesis of positive white male images (Collier-Thomas \& Franklin, 2000; Goines, 1993). As noted by Brittan and Maynard (1984) domination always involves the objectification of the dominated.

Secondly, black female self-definition and self-valuation are significant in terms of allowing black women to reject internalized, psychological oppression (Baldwin, 1980). The potential damage of internalized control to black women's self-esteem can be great, even to the prepared. Enduring the frequent assaults of controlling images requires considerable inner strength. Being treated less than human can be debilitating for black women who are not self-defined (Gwaltney, 1980).

Black feminism is the nexus between the black liberation and the women's liberation movements, but it has its own distinct ideologies. Black feminist thought consists of specialized knowledge created by black women that clarifies a standpoint of and for black women (Lewis, 1977). Thus, black feminist thought encompasses theoretical interpretations of black women's reality by those who actually live it. Black feminist perspectives stress how various forms of gender, race, and class oppression work together to form a matrix of social domination. These oppressions are deeply interwoven into social structures and work together to define the history of the lives of black women in America and other women of color worldwide (Beck \& Jennings, 1982). 


\section{CHAPTER FOUR:}

\section{METHODOLOGICAL APPROACH}

\section{Introduction}

The purpose of this study has been to examine how black domestic workers negotiated their personal and public spheres of life during the Civil Rights Movement. The past few decades of critical analysis point to the emergence of a scholarly consensus about the need to deconstruct the hierarchical binary of an orthodox separate spheres model and to replace it with one that acknowledges that public and private are not stable, unchangeable, or natural polarities (Park and Wald, 1998). The terms public and private spheres have born, and continue to bear, the inscription of ongoing struggles around questions of access to social power, where power is a function of one's location within a social geography of separate spheres (Fraser, 1990).

Some feminist scholars (Barnes, 1993; Cohen, 2003) have elaborated, extended, and amplified critiques of the public/private binary and its relation to the racialized and sexualized division of labor, bringing their insights to bear on the experience of black domestic workers. Davis (1981) took this same approach noting that while black women have been able to circumvent many of the conditions of patriarchal domesticity through their outside work, this work has itself been privatized and relegated to the private sphere of white middle-class women's homes. Davis further argued that the private sphere of middle-class white women's domesticity was constructed through the use of the labor of 
of white middle-class women's homes. Davis further argued that the private sphere of middle-class white women's domesticity was constructed through the use of the labor of working women of color, specifically black women. Hence, white middle-class women's privacy and domestic comfort were dependent on the outside labor of women of color, whose public sphere of work was white middle-class women's private sphere.

In the $1980 \mathrm{~s}$, scholars who researched histories of women of color critiqued separate spheres metaphors calling for attention to the ways in which African American women, in particular, have rarely had the privilege of occupying a strictly domestic realm (Fraser, 1986). Others suggested that separate spheres could only apply to white or middle-class or northeastern women, the subjects of early studies. Such arguments did not diminish the use of separate spheres, but rather increased the utilization of the ideology (Eisenberg and Halev, 2005). Although examined from various vantage points, separate spheres continues to provide an analytical tool for understanding the history of women's and men's relationships of power with each other, with members of their own sex, and with the larger society (Knapp, 2006).

With the historical roots of domestic work intertwined with the institutionalized enslavement of Africans, domestic work by African American women during the 1950s and 1960's, carried many social and political meanings and ramifications (Glenn, 2000; Kelley, 1994; Collins, 1989). Despite the daily challenges of race, class, and gender prejudices, they were able to organize and initiate acts of resistance. Few studies have been done that enhance the visibility of black domestic workers and their activism and resistance to overt oppression. While Jones (2010) included some information regarding the lives of black domestic workers in two chapters of her book, like other writers, the 
information used was not contributed by primary sources, and failed to represent the women's point of view. As such, the overall goal of this study is to collect data from a primary source, the black domestic worker, that reflects their experiences and perspectives.

\section{Objectives}

The purpose of this study is to investigate the life experiences of black domestic workers, the public sphere of their workplace and in the Civil Rights Movement as well as in the private sphere of their home, family and community. To achieve this purpose the study specifically examined the job description and experiences of black domestic workers, the social relationships between themselves and their white female employers, and the role that they played in the Civil Rights Movement. Further, the study sought to investigate the impact of wage employment and social activism on the personal and familial life of the women.

\section{Methodology}

The study adopted a triangulation of data collection methods as a means to validate and cross verify the data collected. This included a thorough interrogation of the literatures on the Civil Rights Movement and the roles of black domestic workers along with semi-structured interviews with 5 domestic workers. The questions of the interview instrument were used as a guide to collect information around the oral histories of the women and used to build a case study of black domestic workers that can be compared to what is reported in the literature. Conducting the interviews were important because it allowed the women to express their own experiences and perspectives on why they 
worked as domestics, the racism that they faced, what coping strategies they adopted, and why they felt compelled to participate in a Movement that was quite radical in its strategies, and one that made them and their families vulnerable to personal dangers. Such oral histories are important because they give voice to those who would otherwise not be included in historical records and reveal the interpretation of the subjects of a study.

The interview was organized around the information required to meet the specific objectives of the study. Audio recordings were made of each interview; notes were taken, and then transcribed by the researcher. The interview questions asked were:

1. What was it like working as a domestic worker in the South?

2. How was your relationship with your employers?

3. How did your family feel about your work as a domestic?

4. How did you become involved with the Civil Rights Movement?

5. What was your role in the Movement?

6. What were your experiences working as a domestic for whites while participating in the Movement?

7. Have you seen the movie The Help? If so, what are your thoughts?

The data collected was used along with the literature to build a case study of black domestic workers. Case studies are commonly used as a research method in social science disciplines (Campbell, 1975; Hersen \& Barlow, 1976). Creswell (2009) describes case studies as a way in which researchers may examine in depth events, activities, and individuals. This intensive analysis can be used for a single case or two or 
three for comparative purposes. In this study, case studies are used in order to retain the holistic and meaningful characteristics of real-life events through interviewing.

\section{Research Population and Sample}

The research population for the study was taken from the South, specifically from the state of Tennessee. The state was selected because of the unique circumstances of the South in the Civil Rights era and also because it was a convenient population for the researcher who is from the same state. The civil rights demonstrations in Nashville, Tennessee stood out among the most noted sit-in activities of the Movement (Fleming, 1995). Black leadership contributed to the abolition of societal restraints that made democracy more real for many Tennesseans (Wynn, 1991). This is the city where the research population for this study was derived. By the 1960 s, nearly ninety percent of black women in the South worked as domestic workers. In the South, the Jim Crow laws required segregation of the black and white communities, and dictated among other things, where black women could and could not work.

The research population had to consist of women who had participated in the Movement while working as domestic workers. With the assistance of a Nashville community leader and the snow-ball approach to sampling, an accumulative sample was located. However, due to health and age, most were not able to participate. Of the sample, five women agreed to participate in this study. The five women ranged from ages seventy-seven to eight-four. They each attended both interview sessions at the Easley Community Center which was named after the grandfather of this researcher. The women voiced their eagerness to participate, and most were familiar with the researcher's family 
which seemed to also put them at ease. For the purpose of confidentiality the names of the domestic workers were changed and are identified in this study as Catherine, Alice, Sarah, Eunice, and Margaret

\section{Data Collection and Analysis}

The interviews were conducted in two sessions and audio taped. In the first interview the women were asked all the questions on the instrument but the information collected was inadequate in some areas. As such, the researcher scheduled a second session to probe specifically on the women's role in the Civil Rights Movement questions four through seven. The women were interviewed individually, and their first sessions lasted for approximately 1 hour. During the second interview, each session ranged from one hour to 1.5 hours. It was during this session that the researcher realized that the interviewees' reluctance to discussing their participation in the Movement was due to their perceptions that their contributions were too minimal to discuss. Once the women were encouraged and prompted to discuss their experiences, they began to recollect their responsibilities in the Movement. Two of the women were prompted by family members who prior to the interview, were unaware that their mother had played an active role in the Civil Rights Movement.

The researcher used the transcription of the tapes and the notes taken during the interview and organized the information around the themes of the specific objectives. First, the women were described, then their work experiences and relationships, their role in the Civil Rights Movement, and then the impact of these experiences on their familial and personal life. A Black feminist theoretical perspective was used to analyze the 
intersectionality of race, class and gender experiences of the black domestic workers. Additionally, the literature review was utilized in order to establish the extent to which the findings differed or were in agreement with prior studies.

\section{Observations}

The women presented for the interview sessions enthusiastically. Each commented on how delighted they were to be asked to share their experiences as they had never been asked about their occupations as domestic workers in the segregated South, nor their work within the Civil Rights Movement. As previously mentioned, during the first interview, the woman mainly discussed their labor as domestic workers.

Each of the women was interviewed separately with at least one family member present. The family members of one respondent, (Eunice), were just as enthusiastic as the interviewees. Her daughter admitted that she had never sat down and talked to her mother about her involvement in the Civil Rights Movement. In fact, she stated that this was something she had never heard her mother discuss. In another case, Margaret's eldest son, who accompanied her for the interview admitted that he remembered his mother working as a domestic worker, but had no idea that she had ever participated in the Movement. Margaret explained that she never related her preparing and cooking meals for Movement leaders as a contribution to the Movement. As for her boycotting of the Montgomery bus system, she stated that one of the goals of the domestic workers was to show a unified front.

Their memories of the racial climate in Nashville during the 1950's and 1960's were all similar to one another. They each recalled not only the racial divisions during 
the time of segregation, but the divisions within the black community concerning whether integration would even be beneficial to Nashville's black communities.

\section{Limitation of Study}

The main limitation of the study is that its findings while in depth cannot be generalized because of its small sample size and specificity of the location of the sample. In addition, the age and health of the research sample posed certain challenges in the actual conduct of the interviews as well as the information collected. Although the women communicated well their experiences using their own words and interpretations there were issues of recollection and had to be prompted at times. The issue of accuracy of their information was cross checked with that of the literature.

In addition, because of their ages and health, all the women were interviewed with family members present. In one case, the family members wanted to hear the experiences they had never known before (which the interviewee gave them consent to do). Another woman asked to have her daughter present for medical reasons. It is uncertain whether having family members present hampered in any way the level of comfort of the women to tell their stories, particularly on issues that were related to their families. Despite the limitations, the information collected was in-depth enough to use with the literature review in order to build a feasible case study. 


\section{CHAPTER FIVE: FINDINGS \\ Roles and Relationships}

\section{Introduction}

Each of the women in this study had families while participating in the Civil Rights Movement. The multiple roles of domestic workers encompassed the isolation of their workplace, their participation in the Civil Rights Movement, and their relationships and responsibilities within their own homes and communities. Their occupation as domestic workers and activists impacted their lives in both public and private spheres.

The five domestic workers interviewed ranged in ages from seventy-one to eighty-four and were all previously married with children. Four are now widows and one divorced.

For the purpose of confidentiality, the study participants have been given fictitious names. Catherine, a quiet soft-spoken seventy-seven year old widow lives in an independent living facility in Nashville, Tennessee. She wears her pure white hair in a braid that nearly reaches her waist, and says that when she looks in the mirror, she sees her mother. She worked as a domestic worker longer than any of the other women in this study. For ten years, she cooked, cleaned, and cared for the children of her employers. She was married and raised two children while working as a domestic. She reported that her mother had also worked as a domestic, and made extra income from ironing in her home on the weekends. Her participation in the Movement consisted of her preparing meals for Freedom Riders. 
Alice, a seventy-eight year old widow, worked as a domestic for 7 years. Her small frame disguises her huge personality and hearty laugh. She lives in the same facility as Catherine, where they often play bridge or bid whist together. During her employment, she cared for the sick and elderly. Alice held picket signs outside of McCrory's and other white segregated businesses in Nashville during the Civil Rights Movement.

Sarah is the youngest of the women interviewed. This spry and optimistic seventy-seven year old has lived with family members for the past five years. Known for her cooking, especially her red velvet cake, she cooked for the students that participated in the sit-ins. Nowadays, she lives quietly at a nursing home, is still active in her church, and enjoys getting visits from her four grandchildren.

Eunice worked as a domestic worker for eight years. She and her husband raised two sons during the Civil Rights era with her spouse working odd jobs. As a domestic worker she cooked and cared for the children of her employer. One of the deacons from her church asked Eunice and her late husband to house Freedom Riders. She shared that she and her husband stayed up all night talking with the students. She said they inspired her to work even harder so that she could send her sons to college. She was so impressed with the bright young black college students who were making a difference.

Margaret is the eldest of the interviewees. At age eighty-four, she knits Afghans for friends and family members, and loves to listen to music. While she only worked as a domestic worker for two years, she says she knew it was not a life she wanted for her daughters. She states that she began working in various factories, until she landed a job with the Ford Glass Plant here in Nashville where she worked until retirement. Her 
husband was a carpenter who sometimes worked as a driver for whites during the Civil Rights era.

The table below shows the demographics of each sample group participant including marital status, age, and number of years worked as a domestic worker.

\section{Demographics of Subjects}

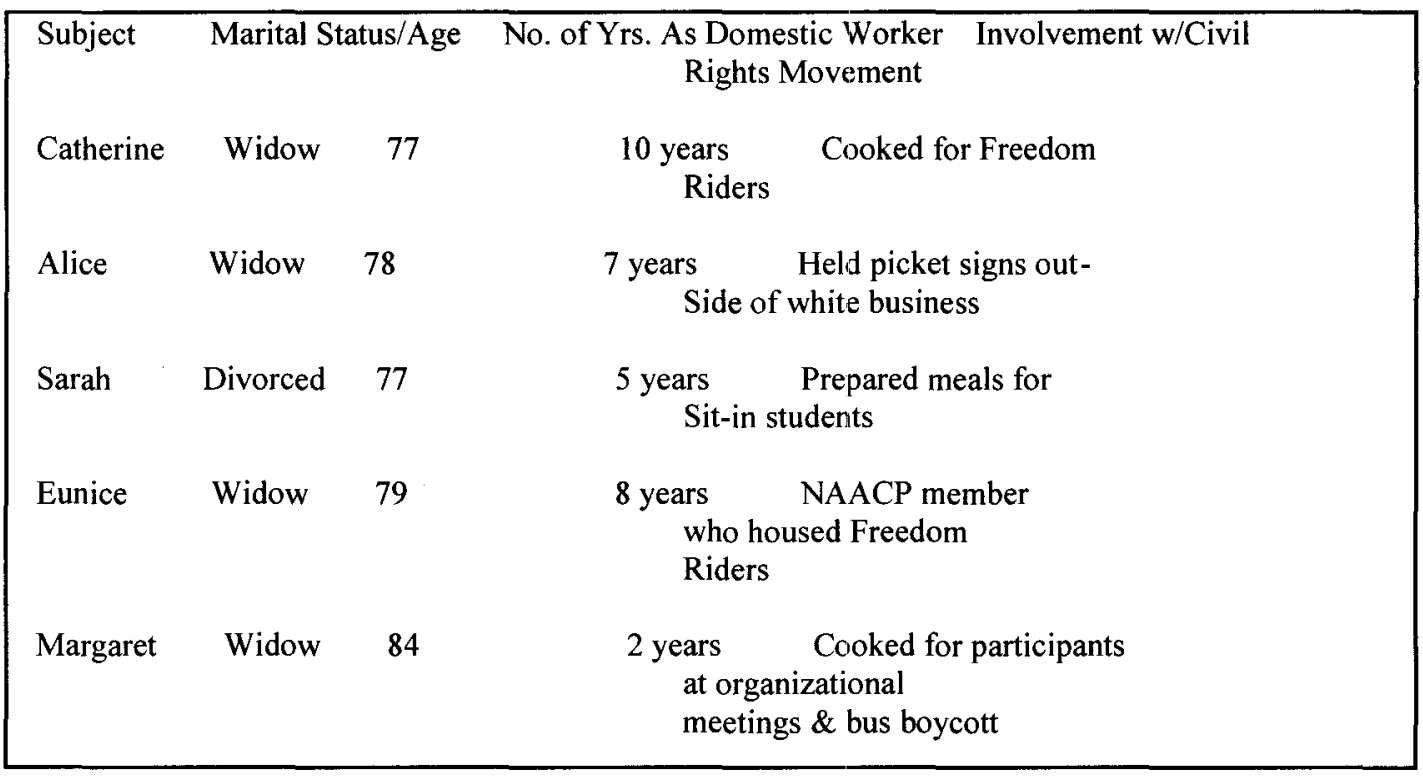

\section{$\underline{\text { Job Descriptions }}$}

While some domestic workers reported that their work was heavily monitored and scrutinized by their employees, others have commented on the freedom they had to determine how to organize their daily chores. They performed a variety of duties within private homes, and their work hours generally began around 7:00 a.m. and ended between 5:00 p.m. and 7:00 p.m. Their hours of work depended on their responsibilities of either preparing meals for their employee and their families, or having to make sure the children of their employees got off to school on time and returned home safely. Each of the women in the study group used public transportation to and from work. Four of the 
women worked six days per week with Sundays off, while one subject worked 5 days per week. The work routines and schedules of domestic workers limited the time they had for their own families and personal lives. However, as reported by the women of this study, they negotiated their time and responsibilities between the public and private spheres of their lives as much as possible.

The duties and responsibilities of the sample group during their time of employment consisted of taking care of the ill and elderly, cooking and cleaning, or a combination of both. Many domestic workers took considerable responsibility for the care of their employer's children.

When asked the interview question, "What was it like working as a domestic worker," the women who performed solely care-taking duties stated they were hired either to care for children or the sick and elderly. Their responsibilities in caring for children varied from seeing the child off to school, attending to the child if illness occurred; making sure homework was done, or entertaining them with game-playing or by reading to them. Additionally, those who cared for children were sometimes relegated to chaperone the child to recreational and social outings as was the case with one interviewee. She was responsible for taking the child to the park, and to sports practices. She explains,

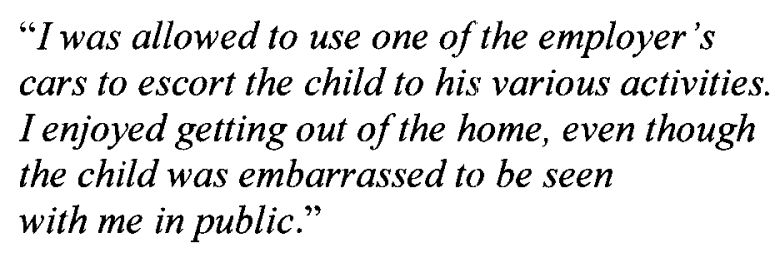

Subjects of the sample group who cared for the sick and elderly described their work as those of a nurse or physical therapist. They stated that they were expected to 
administer medications, bathe and dress the individual, and sometimes even clean and care for wounds. One interviewee who admitted she had no formal nursing experience stated, "I had to draw on my intuition and common sense when caring for the critically ill." Some domestic workers in this study explained that they were also responsible for exercising the limbs of those who had physical limitations. When attending an employer's family member who was bed-ridden, they were expected to be at the bedside, turning them in the bed when needed, and caring for their personal hygiene.

The information shared by the interviewees who performed household duties reported similar accounts of their job responsibilities. Each described their routines for cooking and cleaning. One subject stated,

$$
\begin{aligned}
& \text { "I made sure I cooked their Sunday dinner } \\
& \text { on Saturday since I wouldn't be there, and } \\
& \text { I always did their laundry on Wednesdays." }
\end{aligned}
$$

Along with planning and cooking three meals daily for their employers, most devised their own schedules for chores such as designating certain days to do laundry and ironing. In cases when the work did not meet the expectations of the employers, sometimes drastic measures pursued. For instance, one subject reported that after mopping, she was told that the baseboards were not clean enough. After she made another attempt to satisfy her employer, she was given a toothbrush to use for cleaning baseboards.

\section{Relationships with White Women}

Of the five women, four of them reported they had positive, friendly relationships 
with their employers. In fact in each case, they described the white female employee as one who sought "friendship" and "companionship." One subject recalls,

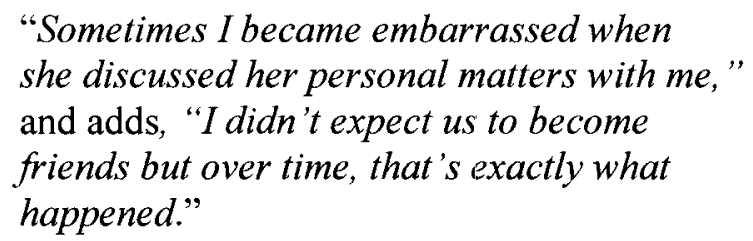

Another interviewee recalled that her employer attended her son's high school graduation, while another stated that she was invited as a guest to her employer's wedding anniversary celebration. However, the women were guarded about the "nature" of the relationships between themselves and their white female employer. For example, one subject reported that she understood that the "friendship" was only while she was in her employer's house working, and was not sustained outside of her employer's home. For instance,

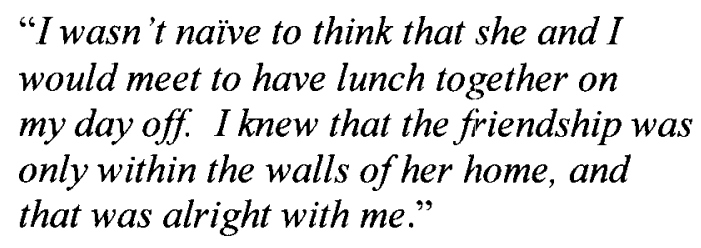

Although most subjects recalled positive employer/employee relationships, they acknowledged that they were well aware of the boundaries of their friendships. As stated by one subject,

\footnotetext{
"Regardless of our friendship, I still called her Miss, and she still called me by my first name."
}

In contrast to these positive images of black/white, employee/employer 
relationships, one woman reported she was inundated with derogatory comments. Besides constant threats of being permanently dismissed, she explicitly recalls being accused of stealing items (which were always found), and being referred to as the "nigger help." She says,

\section{"I bit my tongue and bared it until I could find other work. I was forewarned by others who had worked in this particular home, but Ijust didn't realize it was as bad as it was."}

The degrading and demoralizing way domestic workers have reported to be treated are also experiences that the sample group has either experienced themselves, or have known others to have experienced. Despite the outwardly "friendly" nature of most employees, study subjects reported demeaning aspects of their jobs. Some reported they were unable to use the same bathroom as their employers. As one woman reported,

"I was only allowed to use the bathroom in the basement and before I went home each day, I was required to clean it thoroughly."

Two women stated that their employers assigned to them a particular glass, plate and utensils. They were not allowed to use any other items for the duration of their employment. As one woman put it,

\section{"They actually thought my skin color would contaminate those things. \\ I'm sure they threw them away once I stopped working for them."}

Yet another woman reported that her employer required her to wear gloves while working in their home. She stated, 
"It always seemed like such a silly

thing to me but I finally became

accustomed to it."

Each of these women in the sample group stated that they felt their reputations were heavily dependent upon the personality and disposition of their white employers. One subject stated that an objectionable comment or less than glowing reference from an employer could relegate a domestic worker from further employment as a domestic worker. Subsequently, their relationships with employers had to be constantly nurtured.

The findings also revealed that domestic workers were vulnerable to dismissal on the grounds of pregnancy. Alice reported that she was fired from two jobs once the employers where informed of her pregnancy. She began hiring herself out and ironing for whites until she was able to find another employer and return to work. Other subjects knew of many women who had the same experience.

Catherine and Eunice, who worked the most number of years as domestics, were also the ones who experienced the most derogatory consequences by their employees. Catherine reported that when she first began working as a domestic, she would sometimes make mistakes or accidentally drop or break something. She states that upon reflection, she probably dropped things because when she first began, she was very nervous. She admits that she had never been so close to whites until she began working as a domestic worker. She further states that her employer at the time would call her a stupid nigger girl whenever she made a mistake. As she got older, she witnessed other young domestic workers being called derogatory names.

At the same time, attachment to the white children who were in their care was inevitable. According to one interviewee: 
"I basically raised white children.

Some of them grew up and I never

heard from again, but some sent

me Mother's Day and Chrisimas

cards over the years."

Another subject reported that sometimes the hardest thing to do when transitioning from one job to another was leaving the children you had cared for. However, she also adds,

"I had to think about my own family. My husband worked and he expected me to contribute to the household as well. So if I got offered more money to work in someone else's home, I would take it!"'

'The strained or strange relationship between the black domestic worker and white female employers did not prevent the black women from having some maternal sentiments for the white children in their care.

Each of these women in the sample group stated that they felt their reputations were heavily dependent upon the personality and disposition of their white employers. One subject stated that an objectionable comment or "less than glowing" reference from an employer could relegate a domestic worker from further employment as a domestic worker. Subsequently, their relationships with employers had to be constantly nurtured.

\section{Networking and Activism}

Members of the sample group insisted that the communication chain that linked domestic workers in southern communities was formidable. For instance, all of the interviewees obtained their first domestic jobs through this network. In addition to finding work, they all attest that advice on which families treated domestics well, (and 
those who did not), and where one may find employment, were common pieces of information shared within their circles. According to one subject who lived in Montgomery, Alabama during the bus boycott, information regarding the organizational tactics of the boycott was commonly passed on through the worker's network as well. She reported,
"We would pass information along at bus stops. Then, as we all took our individual buses home, we would inform those riding with us about information pertaining to the boycott. A few times we even designed flyers to alert everyone about our planning meetings while riding the bus. We were doing whatever we could to change our situation."

Catherine reported that she had several employees who consistently made racist

comments while she was in their employment. Alice, who worked for seven years stated,
"I was really young when I began working as a domestic. I figured in order to keep a job, I would have to put up with being talked to as a child-I knew this from what other domestics had told me. I was even warned that I may be called out of my name and I accepted that too. When the activists started meeting with us at the church, it's like I grew a backbone, because once I became involved with the Movement, I started speaking up for myself, and I stopped working for people who treated me like I was just a slave."

One subject had actually viewed The Help at the time of this interview session.

She shared that there had been instances when domestic workers showed resistance to unfair and racist acts. Like those in the movie, she admitted that some domestic workers spoke up for themselves to employers when they felt they were being treated unfairly, 
cheated in their pay, or consistently asked to work extra hours without more pay. She states,

"Occasionally I would hear that someone had walked off the job because her pay was short.

I even walked off a job once for the same reason."

All of the subjects interviewed knew of workers who had exhibited some form of resistance.

\section{Participation in the Civil Rights Movement}

While the first interview session consisted of the women's recollections of their roles as domestic workers, their responsibilities and their relationships with their employers, the second interview was predominately focused on their participation within the Movement. Their reluctance to discuss their involvement during the first interview was very revealing. For Catherine, she stated that she had always felt that the part she played within the Movement was so minimal, that she never felt it was worth discussion. Alice, who worked as a domestic worker for seven years stated that compared to Rosa Parks, her holding picket signs could not compare to what Ms. Parks endured, having to go to jail. Sarah admitted that she was asked by a Movement organizer at her church to cook for some students who were coming into Nashville. She stated that she was not aware they were students who would be participating in the sit-ins downtown until they showed up at her house for dinner. She states that during the time, she never discussed this with anyone for fear of losing her job. Later, she states, "it just seemed insignificant." Eunice, who housed Freedom Riders in her home, states that she was given an award by her church for her contribution to the Movement in 1972 during a 
Women's Day celebration. This has been the only recognition she has ever received. She stated she was surprised to get a call about participating in this research study as she felt no one was interested in her small contribution to the Movement. Margaret, like the other women, admitted that she has rarely reflected on what she feels was a small contribution. She too felt that compared to Diane Nash and other Nashville activists, "It just wasn't worth mentioning."

All of the domestic workers in the sample played a part in the Civil Rights Movement. The subjects reportedly used a few hours during their days off, and specifically on Sundays after church services, to learn about volunteer opportunities within the Civil Rights Movement. At these after-church gatherings, there were usually representatives from the NAACP or Movement recruiters present to inform the community about any recent or upcoming activities. They would also learn of any civil rights infractions that had occurred within their community.

Participation included cooking for Freedom Riders, boycotting the Montgomery bus system, picketing white segregated businesses, preparing meals for sit-in students, housing Freedom Riders, and cooking for participants at meetings. They stated that they felt their actions were very minute in the large scheme of things. However, as they began to discuss their roles within the Movement, they each began to see how their activism helped fuel momentous changes in American society.

For instance, when one interviewee was asked why she was hesitant in discussing her role in the Movement, she admitted that she has rarely mentioned her participation and said, "I didn't do anything as important as Rosa Parks; what I did was small." As one who cooked for the Freedom Riders that inundated her community, she volunteered 
at the urgency of the community leaders in her city. She notes,

"Before we left choir rehearsal one Saturday, some community organizers came to the church and asked if we would be willing to help; that there were some students arriving that would need food and shelter while they were here. I lived in a small place with my husband and two children and knew I couldn't put anyone up for the night, so I told them I would cook."

The interviewee that lived in Montgomery, Alabama during the bus boycott participated in the boycott and as well, picketed white segregated businesses. She remembers,

"We (she and another domestic worker) walked to work and back six days a week for the first two weeks of the boycott. We certainly missed the convenience of riding the bus, but we wanted to do our part in helping to change things for black people. Finally, I told one of the deacons at my church that somebody is going to have to buy me some new shoes. After that, the church made sure we had a ride every day."

Based on her recollection, her employer was aware of her boycotting, as the buses were obviously void of black passengers. However, she states that her biggest worry was her employer finding out about her picketing downtown businesses as several workers she knew had lost their jobs.

Another interviewee was asked by an organizer at her church to help feed the Freedom Riders when they arrived. She went on to say that,

"When I was told I would be responsible for feeding thirty young people who were coming down here to help the Movement, I really didn't understand what they were going to do once they got here. I didn't know that they were possibly 
jeopardizing their lives. Once I saw in the paper and heard from other people that some of the students were being spit on or hit by whites, I volunteered two more times to cook for them. I knew I couldn't do much to help them, but at least they would eat well while they were here."

One woman explains that she was asked to house some of the Freedom Riders.

She states that although her husband was apprehensive about having strangers in their home, he was convinced after talking to organizers that these would be students who would conduct themselves in a mannerly way. She says,
"The group we had in our home only stayed for one night. They were courteous and cleaned up after themselves. I enjoyed listening to them talking about their dreams and goals, and my husband and I prayed with them before they left to head home. I just never thought that what little we did helped the Civil Rights Movement."

Due to one woman working many hours, she reports being unable to participate in the demonstrations that were occurring in her city. She did provide meals for organizers and participants of the Movement. She contends that,

"I knew that if whatever plan they had to change how black people were being treated worked out, things would be better for my sons.

She went on to say, I wanted them to be seen and treated as men."

"I cooked and fed them well. I wanted to make sure they were strong and healthy so they could face the long hard road they were traveling."

The impact that participating in the Civil Rights Movement had on this study's subjects inspired them later in life to become activists for individual causes. One woman, 
who after leaving domestic work began working at a factory, first considered running for a council position in her district but instead, helped to organize a grievance entity at her workplace. Her comments were,

Bing a part of the Civil Rights Movement gave me confidence and self-worth. I began to look at other injustices that I saw around me, and began thinking about how I could help."

After taking time to reflect over her life, another subject declared that perhaps due to witnessing the young Freedom Riders and their enthusiasm for change, this may have influenced her decision to provide both of her sons with a college education. She began,

\section{"I think subconsciously, I wanted my sons to be like those Freedom Riders; smart, and brave."}

The women's accounts of their experiences as activists not only afforded them the opportunity to contribute to the Movement, but in some cases, helped to redefine their worldview. Although their occupations coupled with their activism accounted for their absences at home, they foresaw how both positions would benefit their families in the long run.

In the Movement

\section{Role of The Black Church}

As reported by each of the women in this study, the church was the breeding ground for the recruitment of activists. This is where they were each recruited by either civil rights activists, NAACP members, or other church members. The black church was also where strategy meetings took place, and where the upcoming Movement activities 
were discussed and planned. Subsequently, the black church served as an information center where domestic workers learned of Movement activities and where they were recruited for volunteer opportunities.

By some accounts, black domestic workers who were involved in the Movement experienced sexism by male counterparts. For some, their roles as domestic workers were an image that extended into their roles as activists.

\section{Traditional Role of Women}

The role of black women during the Civil Rights Movement era was repressive and constrictive in many ways. Society placed high importance and many expectations on the behavior of black women at home as well as in public. Women were supposed to fulfill certain roles, such as a caring mother, a diligent homemaker, and an obedient wife .

For domestic workers, this ideology remained as they began to matriculate into the Movement. Alice, one of the subjects of this study reported that she was assigned by male leaders to prepare and cook meals at planning meetings. Although she did not balk at his request, she states that some women refused. While some scholars have argued that most organizations relegated women to positions behind the scenes, or menial jobs, for domestic workers, this meant they were likely to be assigned duties that were typical of domestics. The sexism that was present in the Civil Rights Movement was a continuation of oppressive mentality that existed in the larger U.S. culture.

The roles played by women within the Civil Rights Movement both deviated from and reinforced the gender norms of the era. Many Civil Rights organizations were maledominated; however, some allowed and encouraged female leadership and participation. 
Some women conformed to traditional standards by performing domestic and clerical tasks while others contested such roles. Likewise, some male activists were not receptive to significant female involvement while others incited females to be active in the movement. While some black women were oppressed within the Movement, they were not complacent with their positions of inferiority.

\section{Civil Society Activism}

The Montgomery Bus boycott is usually credited with giving birth to the Civil Rights Movement as it came right on the heels of the historic 1954 Supreme Court ruling proclaiming that separate but equal schools were unconstitutional. A great majority of these passengers were black domestic workers. Margaret, who worked as a domestic worker in Montgomery during the time confirmed that she and many others depended heavily on taking the bus before the boycott. However, she adamantly admits that domestics worked along with community leaders and others to form a system of transporting all workers.

In addition to black domestic workers' involvement with the bus boycott, many domestics served as picket sign holders in front of white segregated businesses. They also helped to prepare recruitment and meeting flyers. Like the women in this study, many domestics volunteered to feed and house out-of-town demonstrators, and worked behind-the-scenes to support the Movement. 
Family and Personal Life

Family Responsibilities

In this study, the families of each of these women were the most important aspects of their lives. They worked in order to provide for their families and to improve their living conditions. In each case, these women spent more time working away from home than they did with their families. They had to rely on family and friends to care for their children while they worked. The time and energy that many black domestics devoted to helping to raise white children was in inverse proportion to the time and energy that they had to spend on their own children. A domestic worker's absence from home deeply affected some of their daughters especially. One subject admitted that her daughter had resentments and feelings of abandonment due to her mother's occupation.

She recalled,

"Years later, when my daughter was grown with children of her own, she saw me reading and hugging on my grandchildren. She told me she wished I had given her attention like that."

One subject confided that it was really difficult leaving her daughter in the care of her sister while she worked. She stated,

"When my daughter was three months old, I had to leave her in order to work. My husband was left to care for her whenever I had to work late. It was difficult for all of us." 
Contrary to the stereotypes of black women and specifically black domestic workers, many of them were married with families, and played various roles within their communities.

Their days off were also spent taking care of their own household responsibilities. Women in the sample group reported that their children were not yet born or were too young to help with laundry and other chores. They also report they made time for their families. The three women who were married during their years of domestic work, state that maintaining close relationships with their spouses was important. They made time for private dinners alone, picnics and movie outings. One subject responded that she and her husband spent their time together by working in their vegetable garden. Those who had children all agreed that the hours spent working as a domestic was hard for their own children. They stated in most cases, their spouse or designated relatives knew more about their children than they did; that many times they learned about the well-being of their children from others. Regardless of their duties as domestic workers, their activism within the Civil Rights Movement, or the demands they faced in their own homes, domestic workers maintained many responsibilities.

\section{Relationship with Spouses}

The relationship between domestic workers and their spouses and mates is another area that is remiss of serious examination. Family and community historically has been an important source of strength for black women. Sustaining a family was not easy given their long hours and low pay and that black women defined themselves by their family roles rather than by their role as workers. 
Each of the interviewees reported the overwhelming support they received from their black male counterparts. The women who were married at the time they worked as domestics reported that their husbands were also employed and helped to support the family whereas in the movie The Help, none of the workers had supportive husbands. The sample group who were single at the time of domestic employment state that boyfriends or male family members were readily available to be a listening ear to their complaints and aggravations. They themselves were experiencing racial intolerances and could relate and provide empathy and support. One woman reported,

"My husband could relate to everything I was feeling. He was enduring the racial slurs and comments by his white co-workers, and I was dealing with the same issue by the white woman I worked for."

Another interviewee noted,

"At night, my husband and I would talk about our dreams for our children and that seemed to ignite us and help us push forward from one day to the next."

From the women's reports, sustaining a family was not easy given their long hours and low pay. Their examples reveal that the black domestic workers defined themselves by their family roles and their roles in the community. Alice commented that,

"At work we, (domestic workers), were seen as cooks, nannies, and cleaning women, but on Sundays, we were deaconesses, ushers, Sunday school teachers, or choir members. Through the

eyes of our community, we were much more than domestics."

Both their family and community were an important source of strength for them, and 
most continued to work after marriage and childbearing.

While the movie The Help portrayed the black family with the stereotypical black male absence, the domestic workers in this study reported strong family ties and supportive husbands. Some even reported that not only were there positive black males in their lives, but also in the lives of many of the workers they came in contact with. One subject noted,

She continues,
"On Sundays I attended church with my family and would see other women who were domestic workers there with their husbands and families as well."

\begin{abstract}
"I was a member of a social club that met once per month. In attendance, there would be many domestic workers and their husbands. There were also women there who were married but their husbands worked out of town but would come home periodically. Our morals and standards were not any less than any other race."
\end{abstract}

\title{
Personal Development
}

Steady employment provided enough money for the women to sustain their own households. Some purchased their own homes while others were able to send their children to college. Collectively, this sample group expressed their satisfaction and pride in their work as well as the enjoyment of securing a good reputation as an honest employee. Such a perspective shows the dignity that upheld their occupations; they saw themselves as professionals. As one woman noted,

"I always had a reputation for taking my time about doing things. I didn't want to 
be known for doing things half way.

I took pride in doing a job well."

\section{The Black Church as a Support}

The role of the black church was also quite instrumental in providing a base of support to domestic workers. In addition to spiritual support, the black church served as a vehicle in providing family social functions, job fairs, and offered opportunities to become activists. It served as a gathering place where domestic workers could share and seek advice from other domestics, and where many took on activist roles. For the subjects of this study, it also became a place where they learned to organize inside and outside of the church.

\section{Women In This Study}

The working women whose lives are examined within this study, moved on to other occupations. Catherine, who labored for ten years as a domestic worker worked for a catering business until she retired. After which, she began a catering business of her own. After working for three families as a domestic worker for seven years, Alice worked for a few years at a factory before settling in as a housewife and mother. Sarah worked for two years as a librarian's assistant after leaving domestic work. She later worked at a daycare before retiring. Eunice continued to work as a domestic worker for a total of eight years, and then became a housewife, only working as a private cook occasionally. Margaret moved to Nashville from Montgomery, Alabama after working for two years as a domestic worker. She worked several odd jobs before securing a job as a school bus driver until she retired. Scholars have argued that women in the Civil 
Rights Movement were in fact the ones that organized the protests and demonstrations that are now largely ascribed to the more well- known leaders. They imply that black women were crucial to the success of the Movement.

\section{Discussions \& Conclusions}

As a group, these women sacrificed the time they could have spent with their families, and jeopardized their employment and possibly their lives in order to support the Civil Rights Movement. Individually, they used whatever skills and talents they had to contribute to the advancement of racial equality. While working in the private homes of whites, they were able to sustain their dignity, take pride in their work, and still maintain active roles within the Movement. They utilized networking and support groups in order to organize themselves in a way that would forward their cause to end racial, socioeconomic and political oppression.

Collectively, they were each affected by their roles as domestic workers which manifested in various ways. For example, the harsh conditions and ten years of what she says was "back-breaking work," Catherine worked to make sure her sons went to college and would not have to work as unskilled laborers. Today, one of her sons is a professor at Howard University and the other is a writer and film-maker with a doctoral degree. On the other hand, Margaret made sure she taught her daughter good work ethic practices, and trained her as a domestic worker as well.

Women in the sample group stated they felt their reputations were heavily dependent upon the personality and disposition of their white employers. One subject stated that an objectionable comment or "less than glowing" reference from an employer 
could relegate a domestic worker from further employment as a domestic worker. Subsequently, their relationships with employers had to be constantly nurtured.

The dichotomy of the "friendly" employer and the "mean-spirited" employer are in some ways predictable, however, despite the physical, emotional, spiritual and economic consequences these women experienced, they emerged with dignity and selfworth. Thus the foremost goal of betterment as noted by Barnes (1993) for these women then was to resist racism.

Until recently, the personal relationships between black domestics and white female employers were never considered worthy of serious study. The world of women working in the home was less visible, and was considered less important, than the often more public lives of men. However, since the emergence of feminist scholarship in the late seventies, research has expanded to include the realities of working women's lives. The women in this study all had similar opinions about racism. They each felt that it was wrong, but they each dealt with it in various ways. For instance, despite the negative and defamatory comments Catherine received while working as a domestic worker, she stated that the support she received from her family and community helped her to withstand racism. She further stated that she knew she was not alone; she sat in the back of the bus with other blacks, and sat in the balcony of the downtown movie theatre designated for blacks with her friends and neighbors. To her, it was just a way of life, but something she knew one day would change. Alice stated that she was not truly aware of racism until she ventured outside of her community. She recalls that there were black-owned grocery stores in her neighborhood and all her teachers had been black. She says it was not until she had to travel to work that she would overhear derogatory comments about blacks, or 
have to succumb to segregated public spaces. She adds that she was taught to say "yes ma'am" and "no ma'am" to whites.

For Sarah, her recollections are quite similar, stating that on most Sundays, she never had to come into contact with whites. She discussed how she and her family and friends all felt that it was wrong, but that their conditions in life would one day change. She adds that although her mother enforced upon her and her siblings to always be polite and docile, her father always emphasized how they should speak up for themselves and not feel bad for being black; but to be proud and to walk with their heads up. She adds that she always knew racism was wrong, but did not feel there was anything she could do about it until she joined the Movement.

Eunice stated as a child, she always got into trouble for defying racism. She recalls being told as a child not to venture into a nearby white neighborhood. Of course, she says, she and her friends would occasionally visit the five and ten cents store that was located in this forbidden area. The storekeeper allowed them to come in and purchase items, however, the children in that area would throw rocks at them where an exchange of rock throwing would take place and then she and her friends would escape back to their neighborhood. She admits that sometimes there wasn't anything they really wanted to buy, they just got satisfaction in throwing rocks at the white children. She said that for her, it was a way of releasing the anger she felt towards whites.

Margaret admits that for her, it was very difficult for her to work for whites while feeling so much disdain for them. She states that the attitude whites had for blacks in Birmingham, was no different from the attitude whites in Nashville held for blacks. She admits that the length of time she spent working as a domestic worker was short 
compared to many because it was so difficult for her to work for people who made it apparent that they felt they were better than her.

The women in his study admitted they knew of black women who had to move in with relatives due to lack of income, or move to another state in order to find work because it was too difficult for them to work as domestics. They contend that the isolation of the occupation, the close proximity workers had with employers, and the racist attitudes by many employers, was something many black women could not tolerate. 


\section{CHAPTER SIX: SUMMARY DISCUSSION \& CONCLUSION}

Women in the study are representative of black women historically in the U.S. in that they were not housewives, but working women, mothers and wives - unlike white middle class women. The social construction of gender defined different roles for the white women and the black women in the study. The black women were domestic workers who worked for the middle class White housewife although they were educated, competent, and skilled enough to be assigned with educating and transporting the white children of their employers. The women worked in the low job classification of domestic worker because those were the only jobs available for most black women in the 1950's and 1960's.

In their workplace, they were further exploited because they were not only of the working class, but also because domestic work occurred in the private sphere of the homes and were therefore non-union and unprotected. The working experiences of black domestic workers was therefore one of triple exploitation and discrimination due to race, class, and gender in the public sphere of society and in the private sphere of the homes of white middle class families where they were ill-treated, denigrated, and humiliated by white women. Interestingly, white women negotiated their gender identity through attempts of friendship with the black domestic workers but exercised their class and race privilege in the way they treated the black domestic workers. This resulted in complex and tense relationships of white superiority and black inferiority within gender. On the 
other hand, black domestic workers negotiated this relationship with white women by the clarity in which they understood that the relationship was not one of real friendship, but one that was a working relationship only and was important to their job security. They understood that there was no relationship outside the white female employer's home.

At the same time, black domestic workers expressed their maternal characteristics with the children of the white families in which they worked, and empathized with them when they had to leave for a change in jobs. Given their work situation, black domestic workers like their predecessors and all working black women, resisted racism and denigration in unique and creative ways as the examples in the interviews show. They also networked and assisted each other in job searches and on the job advice. They assisted other workers in how to deal with white employers, especially the white middle class women. Therefore, when the black domestic workers were exposed to resistance and activism the public sphere of the Civil Rights Movement, they were already engaged in such activism in the private spheres of their work life.

Their involvement in the Civil Rights Movement focused around traditional gender roles of meal preparation, housekeeping, and hosting of protestors and organizers as well as in other forms typical of the Civil Rights Movement such as protests and boycotts. Interestingly while black domestic women's resilience and networking in the private spheres of their jobs was relatively safe, unknown to their employers, their activism in the Civil Rights Movement was one of risk-taking, and presented dangers to their jobs, (could be fired), and their personal safety, (arrested and jailed). Their decision to participate in social activism at any cost indicated the women's commitment to fight 
against racism and discrimination of all kinds and reflects the legacy of their predecessors.

The black domestic workers in the study not only negotiated their race, class and gender as oppressed working women, but also balanced their work life with their family life. They worked because their family depended on their income as the monies earned by their husbands could support the family. This is another example where the social construction of gender that defines the man as the breadwinner was not applicable to the black man and his family. The work that the women did however presented certain dilemmas as it required them to leave their own children to take care of white children as be away from their families overall for a great deal of time. While from the interviews this resulted in some anxiety with children and mothers, it did not cause conflict or family break-ups. Instead, most of the women reported strong relationships with their own children, spouses, their church and community.

In fact, their work experiences and participation in the Civil Rights Movement further strengthened their character, self-esteem, and leadership qualities both in the home and workplace. For example, one of the women left domestic work and became an employee activist in a factory job. Another, encouraged by the resilience of the student protestors was convinced that she must send her own children to college so that they can a better future than she did. None of the women wanted their children to experience the racism, sexism and classism that they endured as domestics.

This study is unique as it encompassed the full spectrum of the lives of women black domestic workers. Unlike The Help, the findings, analysis and discussions are based on the true life stories of black domestic workers. It also provided the complexities 
and nuances of experiences, relationships and perspectives when race, class, and gender intersect. The social activism, coping strategies, networking and sisterhood explained by the women could only be revealed by black domestic workers themselves including the places that this was possible such as at the bus stops and in the black churches. The data also serve to highlight the everyday forms of resistance by women in the workplace as well as in social movements that are sometimes not valued, even by the women themselves.

Most important the research by examining the roles and relationships of the women in their work, in the Civil Rights Movement and in their family gave women human agency in negotiating the public and private spheres of their lives. The paradigm of negating the existence of personal and public spheres is one that black feminists continue to reject. The negation the knowledge and lived experiences of black women that ignores the complexity and diversity of their experiences is based on the assumption that the reality of white middle class women is the reality of all women. 


\section{REFERENCES}

Anderson, B. (2000). Doing the Dirty Work? The Global Politics of Domestic Labour, Zed Books, London.

Andreas, Carol. (1985). When Women Rbel: The Rise of Popular Feminism. New York: Macmillan.

Andrews, Kenneth T. "The Impact of Social Movements on the Political Process: The Civil Rights Movement and Black Electoral Politics in Mississippi." American Sociological Review 62, (1997); (5):800-20.

(2001). "Social Movements and Policy Implementation: The Mississippi Civil

Rights Movement and the War on Poverty, 1965 to 1971." American Sociological Review. Vol. 66, No. 1.

Ani, M. (1994). An African Centered Critique of European Cultural Thought and Behavior. Warner Publishers; New York.

Asante, Molefi K. (1999). The Painful Demise of Eurocentrism: An Afrocentric Response to Critics. Africa World Publishers; Trenton, NJ. 
Baker, Ella and Marvel Cooke. "The Bronx Slave Market," an essay in the Journal of the National Association for the Advancement of Colored People; The Crisis, (1935).

Baldwin, James. (1981). Nobody Knows My Name. New York: Dell Publishers.

Bambara, Toni Cade. (1970). The Black Woman. New York: Penguin.

Barndt, J. (1991). Dismantling Racism: The Continuing Challenge to White America. Minneapolis: Augsburg Fortress Publishers.

Barnes, Annie S. (1993). "White Mistresses and African American Domestic Workers: Ideals For Change." Anthropological Quarterly, Vol. 66, No. 1. Published by The George Washington University Institute for Ethnographic Research.

Barnett, Bernice McNair. (1989). A Structural Analysis of the Civil Rights Movement and the Leadership Roles of Martin Luther King, Jr. Published by the University of Georgia.

"Invisible Southern Black Women Leaders in the Civil Rights Movement: The Triple Constraints of Gender, Race, and Class.” Gender and Society, Vol. 7, No. 2 (Jun., 1993), pp. 162-182. Published by Sage Publications,

Barnett, Bernice McNair, Ira Robinson and Wilfrid Bailey. "The status of husband/father as perceived by the wife/mother in the intact lower class urban Black family." Sociological Spectrum, 4:421-41; (1984).

Barrios, E. (1978). Revolution of the Grassroots Community. State University of New York Press, Albany. 
Beals, John. (1969). Black Power Movement: Rethinking the Civil Rights MovementBlack Power Era. Published by CRC Press.

Beale, Frances (1970). "Double Jeopardy: to be Black and Female." in Toni Cade (ed.), The Black Woman. New York: Signet.

Beck, P., \& M.K. Jennings, “ Pathways to Participation.” American Political Science Review, 76, 94-108; (1982).

Beckwith, Karen. "Lancashire Women Against Pit Closure: Women's Standing in a Men's Movement. Signs: Journal of Women in Culture and Society 21 (4): 1034$69 ;(1996)$.

Belton, Robert. "The 40th Anniversary of Title VIl of the Civil Rights Act of 1964." Hofstra Labor \& Employment Law Journal 22(2):431-72; (2005).

Benford, Robert D., T. Gongaware, and D. Valadez. (2000). Social Movements. In Edgar Borgata and R. Montgomery (eds.). Encyclopedia of Sociology; $2^{\text {nd }}$. Vol. 4. New York: MacMillan Reference.

Berg, A. (2008). Dealing with Domestic Help. Published by Westview Press.

Berger, Peter L. and T. Luckmann, (1966). The Social Construction of Reality: A Treatise it's the Sociology of Knowledge. Garden City, New York: Anchor Books. 
Bermanzohn, Sally A. "Violence, Non-Violence, and the Civil Rights Movement." New Political Science 22.1 (2000): 31-48.

Berrey, Clare. (2009). Generations in Print: Revision in American Literature. Published By ProQuest.

Bhavani, K. and M. Coulson, "Transforming Socialist Feminism: The Challenge of Racism.” Feminist Review, Vol. 23 (1986); 81-92.

Billingsley, A. (1992). Climbing Jacob's ladder: The enduring legacy of AfricanAmerican families. New York: Simon \& Schuster.

Bloom, Brenda. (1987). Parting Waters, America in the King Years 1954-1963. New York, NY: Simon \& Schuster.

Blumberg, Rhoda. (1990). Women and Social Protest. Published by Oxford University Press.

Blumer, Herbert. (1939). Critiques of Research in the Social Sciences: An appraisal of Thomasand Znanicki's The Polish Peasant in Europe and America. Published by the New York Social Science Research Council.

Bobo, Lawrence and Ryan A. Smith. From Jim Crow Racism to Laissez-Faire Racism."Pp. $182-220$ in Beyond Pluralism, edited by W.F.Katkin, N. Landsman, and A. I Tyree. Carson, Claybome (ed). 1998.

Bookman, Ann, and Sandra Morgen,(eds.). (1988). Women and the Politics of Empowerment. Philadelphia: Temple University Press. 
Boris, Eileen. "The Racialized Gendered State: Constructions of Citizenship in the United States," Oxford Journals: Social Politics Vol.2, Issue 2 (Summer 1995): $160-180$.

Boris, Eileen and Jennifer Klein. "We Were the Invisible Workforce: Unionizing Home Care" in D.S. Cobble, The Sex of Class: Women Transforming American Labor. Ithaca: Cornell University Press, (2007), 177-93.

Boris, Eileen and Premilla Nadasen. "Domestic Workers Organize!" In Working USA: The Journal of Labor and Society Vol. 11 Dec. (2008), pp. 413-43. "Power, Intimacy, and Contestation: Dorothy Bolden and Domestic Worker Organizing in Atlanta in the 1960s" In Intimate Labors, ed. Eileen Boris and Rachel Parrenas. Stanford University Press, (2010).

Bracey, Earnest N. (2011). Fannie Lou Hamer: The Life of a Civil Rights Icon. Published by McFarland.

Breines, Winifred. (2007). The Trouble Between Us: An Uneasy History of White and Black Women in the Feminist Movement. Oxford University Press.

Broman, C. L., J.S. Jackson, \& H.W. Neighbors, "Sociocultural Context and Racial Group Identification Among Black Adults." Revue Internationale de Psychologie Sociale, 2, (1989); 367-378.

Brown, Nikki \& Barry M. Stentiford. (2008). Ready From Within, Septima Clark and the Civil Rights Movement Trenton, NJ: African World Press, Inc. 
Bryman, A. (2012) Social Research Methods. Fourth Edition. Oxford: Oxford University Press.

Bullard, Robert D. (2000). Dumping in Dixie: Race, Class and Environmental Quality. Boulder, CO: Westview Press.

Bunch-Lyons, Beverly A. (2002). Contested Terrain: African American Women Migrate from the South to Cincinnati, Ohio, 1900-1950. New York: Routledge.

Burstein, Paul (1985). The Struggle for Equal Employment Opportunities in the United States Since the New Deal. The University of Chicago Press.

Burstein, Paul and W. Freudenberg. "Changing Public Policy: The impact of Public Opinion, Antiwar Demonstrations and War Costs on Senate Voting." American Journal of Sociology; (1978);84: 99-122.

Calhoun-Brown, Allison, "Upon This Rock: The Black Church, Nonviolence, and the Civil Rights Movement," Political Science and Politics, American Political Science Association, Jun., 2000 33:2, 168-174.

Campbell, D. "Degrees of Freedom and the Case Study." Comparative Political Studies, 8, 178-185; (1975).

Candaele, Kelly. Baseball Players Must Act Like a Labor Union. LA Times, Opinion Section; (May 19, 1996). 
Chafe, William Henry. (1972). The American Woman: Her Changing Social, Economic, And Political Roles, 1920-1970. Oxford University Press.

Chafetz, Janet and Anthony Dworkin. (1986). Female Revolt: Women's Movements in World and Historical Perspective. Totowa, N.J.: Rowman and Allanheld, 1986.

Chang, Grace. Disposable Domestics. Cambridge: South End Press, 2000.

Chaplin, David. "Domestic Service and Industrialization." Comparative Studies in Sociology; 1:97, 127; (1978).

Cheek, J. M., \& S.R. Briggs. "Self-Consciousness and Aspects of Identity." Journal of Research in Personality, (1982); 16, 401-408.

Clark-Lewis, Elizabeth. (1994). Living In, Living Out: African American Domestics in Washington, DC, 1900-1940. Smithsonian Institution Press.

Cobble, Dorothy Sue. (ed.). (2004). The Sex of Class: Women Transforming American Labor. ILR Digital Press; Cornell University.

Cohen, Philip N. and Matt L. Huffman. "Occupational Segregation and the Devaluation of Women's Work across U.S. Labor Markets. Social Forces, (2003). 81(3): 881908.

Cohen, William. (1991). Freedoms Edge: Black Mobility and the Southern White Quest for Racial Control 1861-1915. Louisiana State University Press. 
Collier-Thomas, Bettye. (1984). Black Women Achievement Against the Odds. Published By Pierce Manor Community Services.

Collier-Thomas, Betty \& V.P. Franklin. (2000). My Soul is a Witness: A Chronology of the Civil Rights Era 1954-1965. New York, NY: Henry Holt \& Company.

Collins, P. (2000). Black Feminist Thought: Knowledge, Consciousness, and the Politics of Empowerment. ( $2^{\text {nd }}$ ed.). New York: Routledge. (1997). Towards An Afrocentric Feminist Epistemology. In Sandra Keys and Judith Squires (eds.), Feminisms, (pp. 198-206). Oxford: Oxford University Press. (1990). Black Feminist Thought: Knowledge, Consciousness and the Politics of Empowerment. Cambridge:Unwin Hyman.

Collins, C. and D.R. Williams. "Segregation and Mortality: The Deadly Effects of Racism." Sociological Forum Vol. 74, (1999); 495-523.

Collins, William J. "Race, Roosevelt, and Wartime Production: Fair Employment in WWII Labor Markets." Published by the American Economic Review, Vol. 91, No. 1. (March, 2001).

Combahee River Collective. 1981. "A Black Feminist Statement." This Bridge Called My Back: Writings by Radical Women of Color, ed. Cherríe Moraga and Gloria Anzaldúa. Watertown, Massachusetts: Persephone Press. 210-18. 
Cooper, N.I. (1997). In the wake of Flor and Sarah: Analyzing the "mega dramas" of Transnational Dilemmas in Proceedings of the International Conference on Women; Singapore National University.

Coser, Lewis. "Servants: The Obsolescence of Occupational Role." Social Forces 52:31$40 ; 1974$.

Costain, A. and S. Majstorovic. "Congress, Social Movements and Public Opinion: Multiple Origins of Women's Rights Legislation.” Political Research Quarterly. (1994) 47: 111-135.

Cowan, Ruth Schwart. (1983). More Work for Mother: The Ironies of Household Technology from the Open Hearth to the Microwave. New York: Basic Books.

Crawford, Vicki L. (1987). We Shall Not Be Moved: Black Female Activists in the Mississippi Civil Rights Movement, 1960-1965. Ph.D. dissertation, Emory University, Graduate Institute of Liberal Arts.

Crawford, Vicki L., Jacqueline Anne Rouse, and Barbara Woods, eds. (1990). Women in the Civil Rights Movement: Trailblazers and Torchbearers, 1941-1965. Brooklyn, NY: Carlson.

Creswell, J (2009). Research Design: Qualitative, Quantitative, and Mixed Methods Approaches. Los Angeles, CA: Sage Publications. 
Dal la Costa, M. and S. James The Power of Women and the Subversion of the

Community,Falling Wall Press, Bristol. In: Anderson, B. (2001) Just Another

Job? Paying for Domestic Work. Gender and Development, (1972).Vol. 9, No. 1, 25-33.

Das Gupta, Monisha. "Housework, Feminism, and Labor Activism: Lessons from Domestic Workers in New York." Signs: A Journal of Women in Culture and Society 33 (2008): 532-37.

Davis, Angela. 1981. Women, Race, and Class. New York: Vintage.

Davis, Angela and edited by Joy James. (1998). "The Angela Y. Davis Reader." Published by Wiley Publishing.

Davis, Ronald. (1982). Good and Faithful Labor: From Slavery to Sharecropping in the Natchez District, 1860-1890 (Contributions in American History). Greenwood Press.

Degler, Carl. (1980). At Odds. New York: Oxford University Press.

Denning, Michael. (1998). The Cultural Front: The Laboring of American Culture in the Twentieth Century. Published by Verso.

Dill, Bonnie Thornton. "Race, Class, and Gender: Prospects for an All-Inclusive Sisterhood." Feminist Studies, Vol. 9, No. 1 (Spring, 1983), pp. 131-150. Published by: Feminist Studies, Inc. 
Dittmer, John. (1994). Local People: The Struggle for Civil Rights in Mississippi. Chicago: University of Illinois Press.

Drake, St. Clair. (1987). Blackfolk Here and There: An Essay in History and Anthropology. Vols. I and II. Los Angeles: Center for Afro-American Studies, University of California, Los Angeles.

Dudden, Faye E. (1983). Serving Women: Household Service in Nineteenth-Century America. Published by Wesleyan.

Dudziak, Mary. (2000). Cold War Civil Rights: Race and the Image of American Democracy. Princeton: Princeton University Press.

Dunavyevskaya, Raya. (1985). Women's Liberation and the Dialectics of Revolution: Rearching for the Future. Atlantic Highlands, NJ: Humanities Press International.

DWU 2008 report on a meeting at the ILO; Women in Informal Employment: Globalizaing and Organizing.

Ehrenreich, Barbara and D. English. (1978). The Manufacture of Housework in Capitalism and The Family. San Francisco Agenda Publishing Company.

Ehrenreich, B., and A. R. Hochschild. (eds.) "Introduction." Pp. 1-14 in Global Woman:Nannies, Maids, and Sex Workers in the New Economy, (2000).New York: Harry Hold and Company, LLC. 
Eisenberg, A. \& Jeff Spinner Halev (2005). Minorities Within Minorities. Equality, Rights and Diversity, Cambridge: Cambridge University Press.

Errante, Antioinette. "But Sometimes You're Not Part of the Story: Oral History and Ways of Remembering and Telling." Published by Educational Researcher; March, 2000.

Evans, Sara. (1979). Personal Politics: The Roots of Women's Liberation in The Civil Rights Movement and The New Left. New York: Vintage.

Fainstein, Susan S. and Norman Fainstein. 1974. Urban Political Movements. Englewood Cliffs, NJ: Prentice-Hall.

Feagin, J.R. (1991). "The continuing significance of race: anti-Black discrimination in public places." American Sociological Review. 56: 101-116.

Feagin, Joe and Herman Vera. (1994). Liberation Sociology. Westview Press.

Fendrich, James. (1993). Ideal Citizens: The Legacy of the Civil Rights Movement. Albany: State University of New York Press.

Ferree, Myra Marx and Beth B. Hess. (1985). Controversy and Coalition: The New Feminist Movement. Boston: Twayne.

Findlay, James F., "Religion and Politics in the Sixties: The Churches and the Civil Rights Act of 1964," The Journal of American History, June 1990 77:1, 6692. 
Fine, Janice. (2007). "Worker Centers: Organizing Communities at the Edge of the Dream. Published by Cornell University Press and the Economic Policy Institute.

Fisher, S., \& Davis, K. (1993). Negotiating at the margins: The gendered discourses of Power and resistance. New Brunswick: Rutgers University Press.

Fleming, Cynthea. "We Shall Overcome: Tennessee and the Civil Rights Movement." Published by the Tennessee Historical Quarterly (1995).

Floyd, M.F, K.J. Shinew, F.A. McGuire and F.P. Noe. (1994). "Race, class, and leisure activity preferences: marginality and ethnicity revisited.” Journal of Leisure Research. 26: 158-173.

Frankenberg, Ruth. (1993). White Women Race Matters: The Social Construction of Whiteness. University of Minnesota Press.

Franz, C. E. (1994). "Reconstituting the self: The role of history, personality, and loss in One woman's life." In C. E. Franz \& A. J. Stewart (Eds.), Women creating lives: Identities, resilience, and resistance (pp. 213-226). Boulder, CO: Westview.

Fraser, Nancy. "Rethinking the Public Sphere: A Contribution to the Critique of Actually Existing Democracy." Social Text, No. 25/26 (1990), pp. 56-80; Duke University Press.

" Toward A Discourse Ethics of Solidarity," Praxis International, Vol. 5, No. 4 (January, 1986) pp. 425-429. 
Fredrickson, George. (1996). Black Liberation: A Comparative History of Black Ideologies in the U.S, Published by Oxford University Press.

Freeman, Jo.(1983). "On the Origins of Social Movements." Published in Waves of Protest: Social Movements Since the Sixties, (Rowman and Littlefield, 1999, pp. 7-24. Based on a paper written in 1971 and first published in Social Movements of the Sixties and Seventies,.

Freire, Paulo. (1970). Pedagogy of the Oppressed. The Continuum International Publishing Group, Inc.: New York, NY.

Garcia, Alma M. (1994). "Maids No More: The Transformation of Domestic Work.” Frontiers: A Journal of Women Studies, Vol. 14, No. 3, pp. 171-180; Published by: University of Nebraska Press.

Gardiner, Judith K. (2002). Masculinity Studies and Feminist Theory: New Directions. Columbia University Press.

Giddings, Paula. (1984). When and Where I Enter: The Impact of Black Women on Race and Sex in America. New York: Harper \& Row.

Gilkes, Cheryl T. (2000). Black Women's Work as Deviance: Social Sources of Racial Antagonism within Contemporary Feminism. Orbis Books: Wellesley, Mass.

Glenn, Susan A. (2002). Unequal Freedom: How Race and Gender Shaped American Citizenship and Labor. Cambridge: Harvard University Press. 
Goines, David L. (1993). The Free Speech Movement: Coming of Age in the 1960's. Berkeley:Ten Speed Press.

Goldberg, Robert. (1991). "Grassroots Resistance: Social Movements in the Twentieth Century America." Wadsworth Publishing Company.

Gordon, Jennifer. Suburban Sweatshops: The Fight for Immigrant Rights. Cambridge: Belknap, (2005).

Gore, Dayo F. (2010). Radicalism at the Crossroads: African American Women Activists in the Cold War. New York: New York University Press.

Graham, Hilary. "The Concept of Caring in Feminist Research: The Case of Domestic Service." Sage Journals: Sociology; February 1991, Vol. 25, No. 61-78.

Gray, Brenda C. (1993). Black Female Domestics During the Depression in New York City. Published by Routledge.

Greenhouse, Steven. (2008). The Big Squeeze: Tough Times for the American Worker. Published by Knopf.

Guy-Sheftall, Beverly. (1995). "Reflections on the Black Woman's Role in the Communities of Slaves" by Angela Davis included in Words of Fire: An Anthology of African American Feminist Thought. Published by The New Press: New York. 
Gwaltney, John. (1980). Drylongso: A Self-Portrait of Black America. New York: Vintage.

Hacker, Andrew. (1992). Two Nations. New York, NY: Macmillan.

Hall, Jacquelyn and Julia Spruill. "The Long Civil Rights Movement and the Political Uses of the Past." Journal of American History, Vol. 91; (March, 2005).

Harding, Vincent. (1982). There Is A River: The Black Struggle for Freedom in America. Published by Houghton Mifflin Harcourt.

Harley, Sharon. (2002). "Historical Overview of Black Women and Work," a chapter by Francille Rusan Wilson from Sister Circle: Black Women and Work, (1980). Rutgers University Press.

Harrison, Cynthia. (1989). On Account of Sex: The Politics of Women's Issues, 1945 1968. Published by University of California Press.

Hart, Roderick P. (2006). Politics, Discourse and American Society: New Agendas. Published by Rowman and Littlefield.

Hart, Viven. (1994). Bound by Our Constitution: Women, Workers, and the Minimum Wage. Princeton University Press.

Hartmann, Heidi. "Capitalism, Patriarchy, and Job Segregation by Sex." Signs, Vol. 1, No.3, in "Women and the Workplace: The Implications of Occupational Segregation." (1974); Published by The University of Chicago Press. 
Heneghan, Bridget T. (2003). Whitewashing America: Material Culture and Race in the Antebellum Imagination. University Press of Mississippi.

Hersen, M., \& D.H. Bariow, (1976). Single-Case Experimental Designs Strategies for Studying Behavior Change. Elmsford, NY: Pergamon Press Ltd.

Higgs, Robert. "Firm, Specific Evidence on Racial Wage Differentials and Workforce Segregation." American Economic Review, March, 1977.

Hill- Collins, Patricia. (1990). Black Feminist Thought: Knowledge, Consciousness, and the Politics of Empowerment. Boston: Unwin Hyman. (2009). Black Feminist Thought: Knowledge, Consciousness, and the Politics of Empowerment. (Revised). Published by Routledge.

Hochschild, A. R. (1989). The second shift. New York: Avon.

Hogan, Wesley C. (2007). Many Minds, One Heart: SNCC's Dream for a New America. The University of North Carolina Press: Chapel Hill.

hooks, bell. (1981). Aint' I a Woman: Black Women and Feminism. Boston: South End Press.

(1984). From Margin to Center. Boston: South End Press.

(1989). Talking back: Thinking Feminist, Thinking Black. Boston: South End Press, 1989.

Holzer, H. (1996). What employers want: Job prospects for less-educated workers. New York: Russell Sage. 
Hudson-Weems, Clenora. (1994). Africana Womanist: Reclaiming Ourselves. $\left(2^{\text {nd }}\right.$ rev.) Troy: Bedford.

Hull, G. T., \& B. Smith. (1997). "The Politics of Black Women's Studies.” In F. W. Hayes, III (Ed.), A turbulent voyage: Readings in African American Studies (2nd ed., pp. 15-23). San Diego, CA: Collegiate Press. (1993). But Some Of Us Are Brave: All the Women Are White, All the Black Are Men:Black Women's Studies. Published by Feminist Press at CUNY.

Hunter, Tera W. (1998). To 'Joy My Freedom: Southern Black Women's Lives and Labors After the Civil War. Harvard University Press.

Hurt, R. Douglas. (2003). African-American Life in the Rural South 1900-1950. University of Missouri Press.

International Labour Organization (ILO). Global Employment Trends for Women. Geneva: ILO.

Irons, Jenny. "The shaping of activist recruitment and participation: A study of women in the Mississippi civil rights movement." Gender \& Society12: 692-709; 1998.

Jackson, John P. and N. Weidman, (2004). Race, Racism, and Science: Social Impact and Interaction. Santa Barbara, CA: ABC-CLIO.

Jaspin, E. (2007). "Buried in the Bitter Waters: The Hidden History of Racial Cleansing In America." New York: Basic Books. 
Jayawardena, Kumai. (1986). Feminism and Nationalism in the Third World. London: Zed.

Jenkins, Craig, and Charles Perrow 1977. "The Insurgency of the Powerless: Farm Workers'Movements (1946-1972)." American Sociological Review 42: 249-268.

Jenkins, J. Craig. 1983. "Resource Mobilization Theory and the Study of Social Movements." Annual Review of Sociology 9:527-53.

Jetter, A., A. Orleck, and D. Taylor, (1997). "The Politics of Motherhood: Activist Voices from Left to Right." Published by Dartmouth.

Jones, Jacqueline. (1985). American Work: Four Centuries of Black and White Labor. Published by W.W. Norton and Co., Inc. (2010). Labor of Love, Labor of Sorrow: Black Women, Work, and the Family, from Slavery to the Present. Basic Books Publishing: New York, NY.

Johnston, H. and B. Klandermans. (1995). Social Movements and Culture. University of Minnesota Press.

Joseph, Peniel E. (ed.). (2006). The Black Power Movement: Rethinking the Civil RightsBlack Power Era. Rutledge.

Joseph, Gloria and Jill Lewis. (1999). Common Differences: Conflicts in Black and White Feminist Perspectives. South End Press Publishers. 
Kaplan, Temma. "Female Consciousness and Collective Action: The Case of Barcelona, 1910- 1918." Signs, 7:3 (Spring 1982): 545-66.

Katzman, David M. (1981). Seven Days a Week: Women and Domestic Service in Industrializing America. University of Illinois Press.

Kelley, Robin D.G. and Earl Lewis (eds.). (2000). To Make Our World Anew: A History Of African Americans. Oxford University Press, Inc.

(1993). "We Are Not What We Seem: Rethinking Black Working-Class Opposition in the Jim Crow South." Published by the Journal of American History, Vol. 80, No. 1, Kentucky State Reports, file 330, RG 119, NARA.

Kerber, Linda. "Separate Spheres, Female Worlds, Woman's Place: The Rhetoric of Women's History," Journal of American History, No.75, (June 1998): 9-39. (1997). "The Cult of True Womanhood," an essay by Barbara Welter (1966) From Toward an Intellectual History of Women: Essays by Linda K. Kerber." Published by The University of North Carolina Press.

Kessler-Harris, Alice. (1982). Women Have Always Worked. Old Westbury: The Feminist Press.

(2006). "Providers: An Exploration of Gender Ideology in the 1930s," in $A$ Woman's Wage: Historical Meanings and Social Consequences. University of Illinois Press. 
King, Deborah K. "Multiple Jeopardy, Multiple Consciousnesses: The Context of a Black Feminist Ideology." Journal of Women and Culture in Society, Vol. 14, No. 1 (Autumn, 1988), pp. 42-72. Published by The University of Chicago Press.

Kitschelt, Herbert. (1986). The Rise of Left-libertarian Parties in Western Democracies: Explaining Innovation in Competitive Party Systems. Published by Duke University Program in International Political Economy.

Kitwana, Bakari. (2003). The Hip Hop Generation: Young Blacks and the Crisis in African American Culture. Published by Basic Civitas Books.

Klandermans, Bert. (1992). "The Social Construction of Protest and Multi-organizational Fields." Pp. 77-103 in Frontiers in Social Movement Theory, edited by Aldon Morris and Carol McClurg Mueller. New Haven: Yale University Press.

Klarman, Michael J. (1994). "Brown, Racial Change, and the Civil Rights Movement." Virginia Law Review. Vol. 80: 7-150.

Knapp, G.A. (2006) "Race, Class, Gender: Reclaiming Baggage in Fast Traveling Theories" in European Journal of Women's Studies, vol. 12, pp. 249-265.

Kornhauser, William. ((1959). The Politics of Mass Society." Glencoe, Illinois: Free Press.

Kuznicki, Jason. "Never A Neutral State: American Race Relations and Government Power." Cato Journal, Vol. 29, No. 3 ; (Fall, 2009). 
Kvale, Steinar. (1996). InterViews: An Introduction to Qualitative Research Interviewing. Thousand Oaks, CA: Sage Publishing.

Lasch, Christopher. (1977). Women and the Common Life: Love, Marriage and Feminism. Published by W.W. Norton \& Co., Inc; $1^{\text {st }}$ edition.

Lawson, Ronald and Stephen E. Barton. (1980)."Sex Roles in Social Movements: A Case Study of the Tenant Movement in New York City." Signs, 6(2); 230-47.

Lawson, Steven F. "Freedom Then, Freedom Now: The Historiography of the Civil Rights Movement." The American Historical Review, Vol. 96, No. 2, (April, 1991); pp. 456-471.

Lawson, S., C. Payne, and L. Patterson. (1998). Debating the Civil Rights Movement. Lanham: Rowman and Littlefield Publishers.

Lee, Chana Kai. (2000). For Freedom's Sake: The Life of Fannie Lou Hamer. University of Illinois Press.

Lemann, Nicholas. (1991). How the Seventies Changed America. Published by American Heritage Publishing Co., Inc.

Lemelle, S. and R.D.G. Kelley. (1994). Imagining Home: Class, Culture, and Nationalism in the Africa Diaspora. Published by Verso.

Lerner, Guida. (1979). The Majority Finds its Past: Placing Women in History. New York: Oxford University Press. 
Levenstein, Aaron. (1962). Why People Work. New York: Crowell.

Lewis, Diane K. (1977). “A Response to Inequality: Black Women, Racism, and Sexism." Signs, Vol. 3, No. 2. Published by: The University of Chicago.

Lincoln, E. C., \& Mamiya, L. W. (1990). The black church in the African-American experience, Durham, NC: Duke University Press.

Lipsitz, George. (1995). "The Possessive Investment in Whiteness: Racialized Social Democracy and the White Problem in American Studies." American Quarterly, Vol.47, No.3. The Johns Hopkins University Press.

Loewen, James W. (2006). Sundown Towns: A Hidden Dimension of American Racism." Simon \& Schuster.

Logan, Rayford W. (1954). The Negro in American Life and Thought: The Nadir, 18771901. Published by Dial Press.

Lovett, Bobby L. (2005) The Civil Rights Movement In Tennessee: A Narrative History. The University of Tennessee Press/Knoxville.

Luders, Joseph E. "Civil Rights Success and the Politics of Racial Violence." Polity, ] Vol. 37, No. 1, Fashion for Democracy (Jan., 2005). Published by Palgrave Macmillan Journals, pp. 108-129.

McAdam, Doug. (1982). Political Process and the Development of Black Insurgency 1930 - 1970." Chicago: University of Chicago Press. 
"Recruitment to high-risk activism: The case of Freedom Summer." American Journal of Sociology, 92:64-90; (1986).

(1988). Freedom Summer. New York: Oxford University Press.

"Gender as a Mediator of the Activist Experience: The Case of Freedom

Summer." American Journal of Scociology; 97:1211-40; (1992).

McAdam, Doug and David A. Snow. (2009). Readings on Social Movements: Origins, Dynamics, and Outcomes. Oxford University Press, $\left(2^{\text {nd }}\right.$ Ed.).

McCann MW. and March T. "Law and everyday forms of resistance: a socio-political assessment." Stud. Law Political Sociology. 15:207-36

McClaurin, I., (ed.). (2001). Black Feminist Anthropology. New Brunswick NJ: Rutgers University Press.

McClendon, M.J. "The Occupational Status Attainment Processes of Males and Females." American Sociological Review 41, (1972), 52-65.

McCourt, Kathleen. (1977). Working Class Women and Grassroots Politics. Bloomington: Indiana University Press.

McDuffie, Erik S. "Esther V. Cooper's The Negro Woman Domestic Worker in Relation to Trade Unionism: Black Left Feminism and the Popular Front." American Communist History, Vol. 7, No. 2 (2008). 
McGrew, Jannell reporter for the Montgomery Advertiser; interview on November 13, 2006 with Johnnie Carr.

McGuire, Danielle L. (2010). At the Dark End of the Street: Black Women, Rape and Resistance - A New History of the Civil Rights Movement from Rosa Parks to the Rise of Black Power. Published by Knopf.

McLoyd, V. C. (1998). "Changing demographics in the American population:

Implications for research on minority children and adolescents." In V. C. McLoyd \& L. Steinberg (Eds.), Studying minority adolescents: Conceptual, methodological and theoretical issues (pp. 167-182). Mahwah, NJ: Lawrence Erlbaum.

Mahnaz Kousha. "Race, Class and Intimacy in Southern Households: Relationship between Black Domestic Workers and White Employers" In Neither Separate Nor Equal: Women, Race and Class in the South. Ed. Barbara Ellen Smith. Temple University Press, (1999); 77-90.

Malveaux, J.M. (1988). Slipping Through the Cracks: The Status of Black Women. New Brunswick, NJ: Transaction Books.

Mann, Susan A. "Slavery, Sharecropping, and Sexual Inequality." Signs, Vol. 14, No. 4, Common Grounds and Crossroads: Race, Ethnicity, and Class in Women's Lives (Summer, 1989), pp. 774-798. Published by: The University of Chicago Press. 
Mannheim, Karl. [1936] 1968. Ideology and Utopia: An Introduction to the Sociology of Knowledge. Translated by Louis Wirth and Edward Shils. New York: Harcourt, Brace \& World.

Margolis, Maxine L. (1984). Mothers and Such: Views of American Women and Why They Changed. Published in Berkeley and Los Angeles: University of California Press.

Martin, J. M., \& Martin, E. P. (2002). Spirituality and the Black helping tradition in Social work. Washington, DC: National Association of Social Workers.

Martin, Linda and K. Segrave. (1985). The Servant Problem: Domestic Workers in North America. Jefferson, NC: McFarland.

Massey, D. \& Denton, N.A. (1993). American apartheid: Segregation and the making of the underclass. Cambridge: Howard University Press.

Massey, D.S., M.J. White, and V. Phua, V. (1996). "The Dimensions of Segregation Revisited." Sociological Methods and Research, 25, 172-206.

1

May, Vanessa. (2011). Unprotected Labor: Household Workers, Politics, and MiddleClass Reform in New York, 1870-1940. Published by The University of North Carolina Press.

Meier, August and E. Rudwick. (1976). From Plantation to Ghetto. ( $3^{\text {rd }}$ edition). Published by HarperCollins: Canada. 
(1989). CORE: A Study in the Civil Rights Movement 1942-1965. Published by Urbana University of lllinois Press.

Melosh, Barbara. (1991). Engendering Culture: Manhood and Womanhood in New Deal Public Art and Theater. Published by: Smithsonian.

Melucci, Alberto. (1989). Nomads of the Present: Social Movements and Individual Needs in Contemporary Society. Philadelphia, PA: Temple University Press.

Meyer, D. S. (2006). The Politics of Protest: Social Movements in America. New York: Oxford University Press.

Meyerowitz, Joanne J. (1991). Women Adrift: Independent Wage Earners in Chicago, 1880- 1930. University of Chicago Press.

Meyers, Marian. "African American Women and Violence: Gender, Race, and Class in the News." Critical Studies in Media Communications, Vol. 21, No. 2, (June 2004), pp. 95- 118 .

Midttun, Atle, and Dieter Rucht. "Comparing Policy Outcomes of Conflicts Over Nuclear Power: Description and Explanation." In States and Anti-Nuclear Movements, edited by Helena Flam, 383-415; (1994). Edinburgh: Edinburgh University Press.

Miles, M. B., \& A.M. Huberman, (1994). Qualitative data analysis: An expanded Sourcebook (2nd ed.). Thousand Oaks, CA: Sage. 
Milkman, Ruth. (2006). L.A. Story: Immigrant Workers and the Future of the U.S. Labor Movement. New York: Russell Sage Foundation.

Mississippi State Reports, file 330, Records of the National Youth Administration, RG 119, NARA.

Mitchell, Erin Goseer. Born Colored: Life Before Bloody Sunday. Ampersand, Inc.: Chicago, Il. (2006).

Mjagkij, Nina. (2001). Loyalty in Time of Trial: The African American Experience During World War I. Rowman and Littlefield Publishers.

Moore, Robert M. (1981). The Hidden America: Social Problems in Rural America for the Twenty-First Century. First printing by Associated University Press.

Morgan, Joan. (1999). When Chickenheads Come Home to Roost: My Life as a Hip-Hop Feminist. New York: Simon \& Schuster.

Morris, Aldon D. (1984). The Origins of the Civil Rights Movement: Black Communities Organizing for Change. New York: The Free Press.

Mustard, D. B. (2001). "Racial, Ethnic, and Gender Disparities in Sentencing: Evidence from the U.S. Federal Courts." Journal of Law and Economics, 44, 285-314.

Naples, Nancy A. (1992). "Activist mothering: Cross-generational continuity in the Community work of women from low-income urban neighborhoods." Gender \& Society, Vol. 6:441-63. 
(1998). Grassroots Warriors: Activist Mothering, Community Work, and the War on Poverty. Psychology Press.

Newman, Debra L. (1977). "Selected Documents Pertaining to Black Workers Among The Records of the Department of Labor and Its Component Bureaus, 19021969." National Archives Special List No. 40.

Newman, Louise Michele. (1999). Women's Rights: The Racial Origins of Feminism in the United States. Oxford University Press.

Nieman, Donald G., (ed.). From Slavery to Sharecropping: White Land and Black Labor in the Rural South, 1865-1900. New York: Garland, 1994.

Oberschall, Anthony. "Loosely structured collective conflict: a theory and an application." Research to Social Movements, Conflicts and Change 3:45-68; (1981).

Olson Lynne. (2002). Freedom's Daughters: The Unsung Heroines of the Civil Rights Movement from 1830 to 1970 . Published by Scribner.

Oommen, T.K. (1990). Protest and Change: Studies in Social Movements. Sage Publishing.

Palmer, Phyllis. (1989). "Domesticity and Dirt: Housewives and Domestic Servants in the United States, 1920-1945. Temple University Press. 
"Black Domestics During the Depression: Workers, Organizers, Social

Commentators." Special Issue: Federal Records and African American History

(Summer 1997, Vol. 29, No. 2.

"Outside the Law: Agricultural and Domestic Workers Under the Fair Labor

Standards Act," Journal of Policy History 7 (1995): 416-440.

Park, You-Me, and Gayle Wald. (1998). "Native Daughters in the Promised Land:

Gender, Race, and the Question of Separate Spheres." In No More Separate Spheres! A Next Wave American Studies Reader. Eds. Cathy N. Davidson and Jessamyn Hatcher; New Directions in Women's Studies. Durham, NC: Duke UP, 2002. 263-87.

Parrenas, Rachel Salazar. Servants of Globalization: Women, Migration and Domestic Work. Palo Alto: Stanford University Press, 2001.

Payne, Charles. "Ella Baker and Models of Social Change.” Signs, 14:885-90; 1990. (1995). I've Got the Light of Freedom: The Organizing Tradition and the Mississippi Freedom Stuggle. University of California Press.

Phillips, C. (2007) 'The re-emergence of the 'Black Spectre': Minority professional associations in the post-Macpherson era', Ethnic and Racial Studies, 30(3) 375396. 
Piven, F.F. and Richard Cloward. (1979). Poor People's Movements: Why They Succeed, How They Fail. Published by Vintage Books.

Poo, Ai-Jen and Eric Tang. "Domestic Workers Organize in the Global City." In The Fire This Time. New York: Anchor Books, 2004: 150-165.

Raaphorst, D. (1988). Union Maids Not Wanted: Organizing Domestic Workers, $1870-$ 1940. Published by John W. Doull, Canada.

Raatma, Lucia. (2008). Selma's Bloody Sunday. Compass Point Books.

Ransby, Barbara. (2005). Ella Baker and the Black Freedom Movement: A Radical Democratic Vision. The University of North Carolina Press.

Reed, Thomas V. (2005). The Art of Protest: Culture and Activism From the Civil Rights Movement to the Streets of Seattle. University of Minnesota Press.

Rivchin, Julie Yates. "Building Power Among Low-Wage Immigrant Workers: Some Legal Considerations for Organizing Structures and Strategies." In NYU Review of Law and Social Change,(2004): 418-24.

Robinson, Jo Ann Gibson. (1987). The Montgomery Bus Boycott and the Women who started it.Knoxville: University of Tennessee Press.

Robnett, Belinda. (1997). How Long? How Long?: African American Women in the Stuggle for Civil Rights. Oxford University Press. 
Romero, M. (1992). Maid in the U.S.A. New York: Routledge.

Rose, Thomas and John Grenya. (1984). Black Leaders: Then and Now. Garrett Park, MD: Garrett Park Press.

Rothman, S.M. (1978). Woman's Proper Place: A History of Changing Ideals and Practices, 1870 to the Present. New York: Basic Books.

Royce, Edward C. (1993). The Origins of Southern Sharecropping. Philadelphia: Temple University Press.

Rubel, David. (1990). Fannie Lou Hamer: From Sharecropping To Politics. Silver Burdett Press, Inc. Englewood Cliffs, New Jersey.

Rudig, Wolfgang. (1990). Green Politics One. Published by Carbondale and Edwardsville: Southern Illinois University.

1

Rupp, Leila and Verta Taylor. (1987). Survival in the Doldrums: The Amerian Women's Rights Movement, 1945 - 1960. New York: Oxford University Press.

Sacks, Karen. (1988). Caring by the Hour. Urbana: University of Illionois Press.

Sacks, K. and D.Remy. (1984). My Troubles Are Going to have Trouble with Me. New Brunswick, NJ: Rutgers University Press.

Sargeant, Malcolm and M.Giovannone. (2011). Vulnerable Workers: Safety, Well-Being and Precarious Work. Gower Publishing Ltd. 
Saville, Julie. "From Slavery to Sharecropping, The Origins of Southern Sharecropping by Edward Royce. Reviewed by Daniel W. Crofts. Reviews in American History, Vol. 23, No. 3 (Sep., 1995), pp. 458-463; Published by: The John Hopkins University Press.

Schneider, M., Tucker, G., Scovak, M. and Wexlerder, M. (1998). The Professional Housekeeper. Published by Wiley.

Schramm-PPage, Susan and Rhonda B. Jeffries (eds.). (2008). Grappling with Diversity: Readings on Civil Rights Pedagogy and Critical Multiculturalism. State University of New York.

Scott, James C. (1997). Weapons of the Weak: Everyday Forms of Peasant Resistance. Yale University Press.

Sen, A. (1999). Development As Freedom. Knopf Publishing: New York.

Sharpless, Rebecca. (2010). Cooking in Other Women's Kitchens: Domestic Workers in The South, 1860-1960. Chapel Hill: University of North Carolina Press.

Shaw, Nate. (1984). All God's Dangers:The Life of Nate Shaw. New York: Vintage.

Shorter-Gooden, K. and K. Jones. (2004). Shifting: The Double Lives of Black Women in America. Published by Harper Collins.

Smedley, A. (2012). Race in North America: Origins, an Evolution of a Worldview. Westview Press. 
Smith, A. (2003). Work, Employment and Transition: Restructuring Livelihoods. London and New York: Routledge.

Smith, Barbara. (ed.) (2000). Home Girls: A Black Feminist Anthology. Rutgers University Press.

Smith, Christian. "Correcting a Curious Neglect, or Bringing Religion Back In"”, In C. Smith (ed.), Disruptive Religion: The Force of Faith in Social-Movement Activism (New York: Routledge): 1-27; (1996).

Smith, Peggie R. "Work Like Any Other, Work Like No Other: Establishing Decent Work for Domestic Workers." Washington University in St. Louis Legal Studies Research Paper No. 12-05-30; Employee Rights and Employment Policy Journal, Vol. 51, No. 157, (2011).

Smith, Ryan A. "Race, Gender, and Authority in the Workplace: Theory and Research." Annual Review of Sociology, Vol. 28: 509-542; (August, 2002).

Springer, Kimberly. "Third Wave Black Feminism?" Signs, Vol. 27, No. 4 (Summer 2002), pp. 1059-1082.

Staples, Robert. "The Myth of the Black Matriarchy," in his The Black Family: Essays and Studies; (1971). Wadsworth: Belmont, California.

Steinberg, S. (1998) The Liberal Retreat from Race during the Post-Civil Rights Era, in: W. Lubiano (ed.), The House that Race Built (New York, Vintage Books). 
Stetson, K. (1990). Jim Crow Guide to the U.S.A.: The Laws, Customs and Etiquette Governing the Conduct of Nonwhites and Other Minorities as Second Class Citizens. Published by The University of Alabama Press.

Stichter, Sharon B. and Jane L. Parpart, (1988). Patriarchy and Class: African Women in the Home and Workforce. Boulder \& London: Westview Press, pp. 205-219.

Strasser, S. (1982). Never Done: A History of American Housework. New York: Pantheon Books.

Sugrue, Thomas. (2008). Sweet Land of Liberty: The Forgotten Struggle for Civil Rights in the North. Random House Publishers.

Sutherland, D. E. (1981). Americans and their Servants: Domestic Service in the United States from 1800 to 1920 . Baton Rouge: Louisiana State University Press.

Swain, Martha H. (2005). New Deal Advocate for Woman. University Press of Mississippi. Tait, Vanessa. (2005). Poor Workers'Unions: Rebuilding Labor From Below. Cambridge: South End Press.

Tarrow, Sidney. (1994). Power in Movement. Cambridge: Cambridge University Press.

Taylor, V. and N.E.Whittier. (1995). "Analytical Approaches to Social Movement Culture: The Culture of the Women's Movement." In: H. Johnston and B. Klandermans (Eds.), Social Movement and Culture. (Pp. 163-187). Minneapolis: University of Minnesota Press. 
Thomis, Malcolm and Jennifer Grimmett. (1982). Women in Protst, 1800-1850. New York: St. Martin's.

Thompson, William. (1988). Appeal from One Half the Human Race. (London:

Longman,Hurst, Rees, Ome, Brown \& Green, 1835). This is excerpted from Dale Spender's "Women of Ideas: And What Men Have Done to Them." London: Pandora Press.

Tilly, L. and Wallach Scott, J. (1978). Women, Work and Family. New York: Holt, Rinehart and Winston.

Tilly, C. and Lesley J. Wood. (2009). Social Movements, 1768-2008. (2 ${ }^{\text {nd }}$. Ed.). Published by Paradigm Publishers.

Tucker, Susan. (1987). Telling Memories Among Southern Women: Domestic Workers and Their Employees in the Segregated South. Published by Pantheon Books a Division of Random House, Inc.

Turner, Ralph H. and Lewis M. Killian. (1987). Collective Behavior. Published by Prentice Hall College Division.

Turner, Johathan, Royce Singleton an David Musick. (1984). Oppression: A socio-history of Black-Whit Relations in America. Chicago: Nelson Hall Publishers.

WPA of Louisiana New Release, Oct. 24, 1940, Information Service Primary File, 824A, RG 69, NARA. 
Warhol-Down, R. and Herndl, D. (2009). Feminisms Redux. Published by Rutgers University Press.

West, Guiad and Roda Lois Blumberg. (1990). Woman an Social Protest. Oxford University Press.

White, Deborah G. (1999). Ar'n't I a Woman?: Female Slaves in the Plantation South. W.W.Norton \& Company.

White, Jaquelyn W., C. Travis and J. White. (2000). Sexuality, Society, and Feminism. Published by the American Psychological Association.

Woodman, Harold D. (1995). New South, New Law: The Legal Foundations of Credit and Labor Relations in the Postbellum Agricultural South. Baton Rouge: Louisiana State University Press.

Wool, Harold. (1976). Labour Supply for Lower-level Occupations. Published by Praeger Publishing, Inc.

Wynn, Linda T. "The Dawning of a New Day. The Nashville Sit-Ins, February 13 - May 10, 1960.." Tennessee Historical Quarterly (1991).

Yin, R. K. (1984). Case Study Research: Design and methods (1st ed.). Beverly Hills, CA: Sage Publications. 
Younts, C. Wesley and C.W.Mueller (2001). "Justice Processes: Specifying the Mediating Role Of Perceptions of Distributive Justice." American Sociological Review. Vol. 66, No. 1. Published by American Sociological Association.

Zaretsky, Eli. (1976). Capitalism, the Family, and Personal Life. New York: Harper and Row. 


\section{CURRICULUM VITAE}

Name: $\quad$ Trena E. Armstrong

Address: $\quad 1402$ Bell Trace Drive

Antioch, TN 37013

DOB: $\quad$ October 24,1958

\section{EDUCATION:}

$12 / 19 / 2009$

Bachelor of Science Degree from Tennessee State University, Nashville, Tennessee - Major: Africana Studies.

$2010-2012$

Master of Arts Degree from University of Louisville, Louisville, Kentucky - Major: Pan-African Studies

STUDY ABROAD:

2009

Research Expedition to Kemet (Egypt) - Tennessee State

University

2011

Trinidad/Tobago - University of Louisville

\section{MEMBERSHIPS and POSITIONS HELD:}

Association for the Study of African American Life and History (2008-Present)

Association for the Study of Classical African Civilizations (2008-Present)

Vice President of Het Heru Sorority, Inc. (2008-2009); Tennessee State University

Secretary of Pan-African Studies Graduate Association (2010-2011); University of Louisville

Treasurer of Pan-African Studies Graduate Association (2011-2012); University of Louisville

Graduate Teaching Assistant (2009 - 2012); University of Louisville 


\section{TALKS:}

"Tennessee State University's First Research Expedition to Egypt." A presentation discussing the sites visited and overall experience.

The $27^{\text {th }}$ Annual ASCAC (The Association for the Study of Classical African

Civilizations) Studies Conference. Columbia, SC. March 6, 2009.

"Addiction in the African American Community."

A seminar discussing the causes and solutions for addiction among African Americans.

Millennium Maxwell House Hotel. Nashville, TN. September 12, 2008.

"Know Thyself."

A presentation on the literary contributions of African Americans in the U.S. Hannah's House Recovery Home. Nashville, TN. March 18, 2006.

"Health is Wealth."

A presentation discussing the benefits of eating organic foods and avoiding fast food and processed foods. Seminar on Health in the African American Community. Easley

Community Center. Nashville, TN. October 10, 2005.

\section{TEACHING EXPERIENCE:}

$8 / 2010-5 / 2012$

Graduate Teaching Assistant

University of Louisville - Louisville, Kentucky

Department of Pan-African Studies

Assisted with the Faces of Global Poverty, an undergraduate

course

May 2012 - Present

Adjunct Professor

Tennessee State University - Nashville, Tennessee Department of History, Geography, Political Science and Africana Studies

Currently teaching 78 undergraduates in three classes; Introduction to Africana Studies, African-American Female Identity, and West African Extended Family. 